
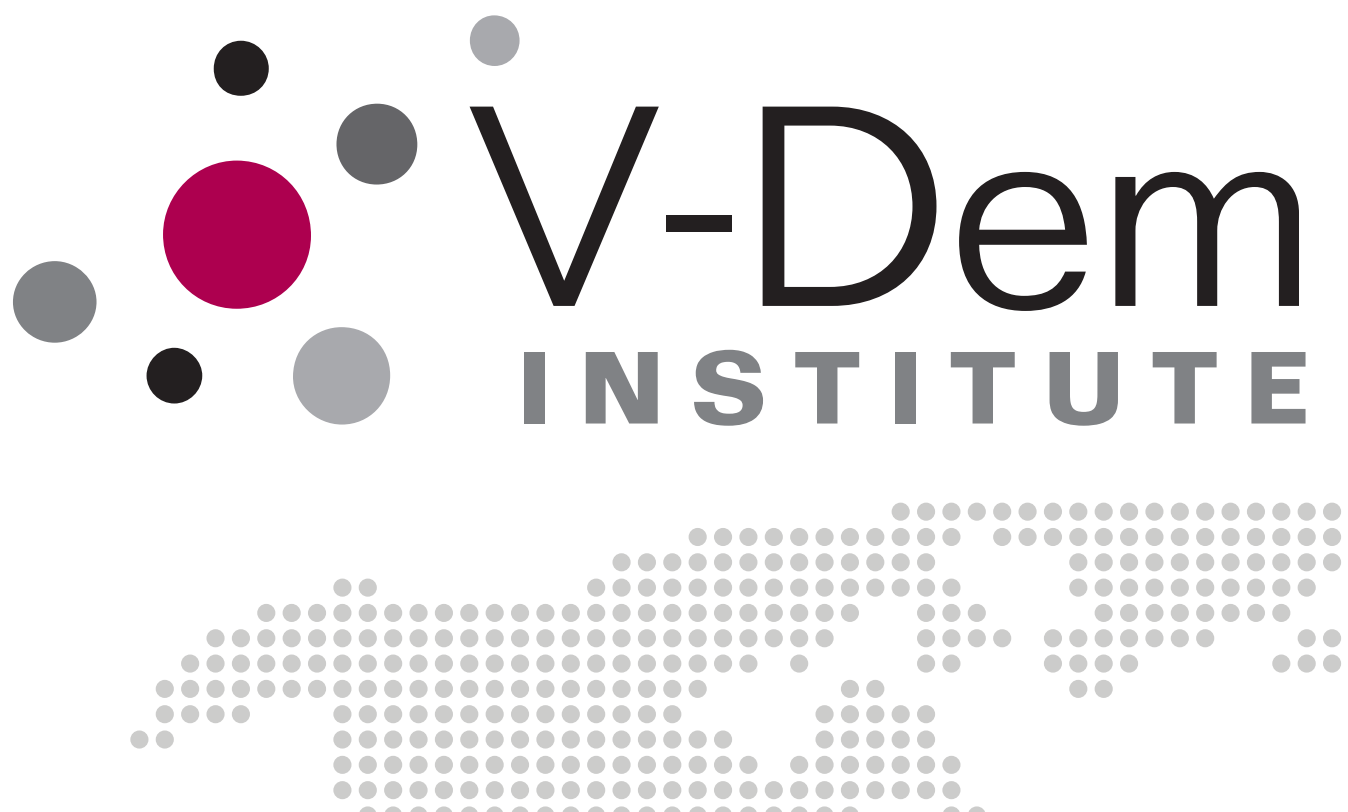

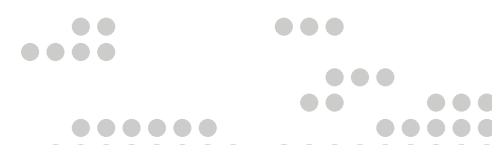
6rob

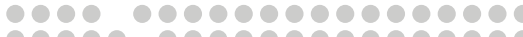

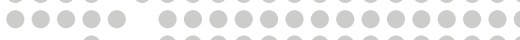
-

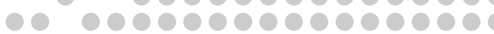

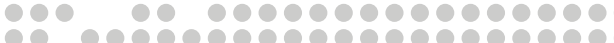

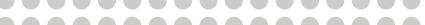

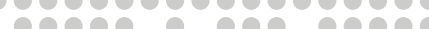
10.080

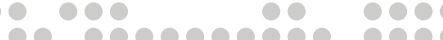

The Varieties of Democracy Core Civil Society Index

Michael Bernhard, Eitan Tzelgov, Dong-Joon Jung, Michael Coppedge and Staffan I. Lindberg
00000000

0000000

000000

100000

1000

000

000

10

10

80

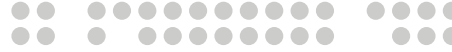

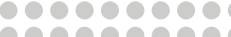

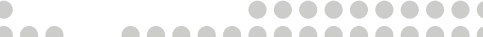

Tor 0000000000000 1000000000000000

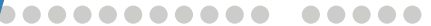


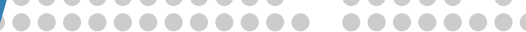

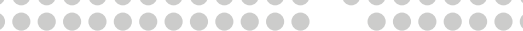
00000000000000000

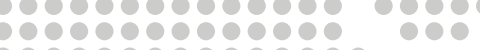

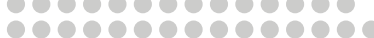

30000900000000000000 000000000000000000 10000000000000000

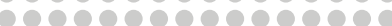

\%०000000000000

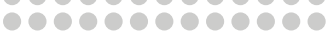

0000000000

0000000000

1000000000

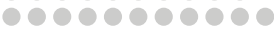

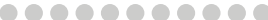

69000000000

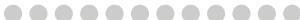

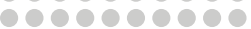

6roberó

098000000

100000

100000

000000

1000

100

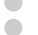

(n)

ชe

10

80

10

10 
Varieties of Democracy (V-Dem) is a new approach to the conceptualization and measurement of democracy. It is co-hosted by the University of Gothenburg and University of Notre Dame. With a V-Dem Institute at University of Gothenburg that comprises almost ten staff members, and a project team across the world with four Principal Investigators, fifteen Project Managers, 30+ Regional Managers, 170 Country Coordinators, Research Assistants, and 2,500 Country Experts, the V-Dem project is one of the largest-ever social science research-oriented data collection programs.

Please address comments and/or queries for information to:

V-Dem Institute

Department of Political Science

University of Gothenburg

Sprängkullsgatan 19, PO Box 711

SE 40530 Gothenburg

Sweden

E-mail: contact@v-dem.net

V-Dem Working Papers are available in electronic format at www.v-dem.net.

Copyright (C) 2015 by authors. All rights reserved. 


\title{
The Varieties of Democracy Core Civil Society Index*
}

\author{
Michael Bernhard \\ Ehrlich Chair of Political Science \\ University of Florida \\ Eitan Tzelgov \\ Postdoctoral Scholar \\ V-Dem Institute \\ University of Gothenburg \\ Dong-Joon Jung \\ Visiting Research Fellow \\ Seoul National University \\ Michael Coppedge \\ Professor of Political Science \\ University of Notre Dame \\ Staffan I. Lindberg \\ Professor of Political Science \\ Director, V-Dem Institute \\ University of Gothenburg
}

\footnotetext{
* This research project was supported by Riksbankens Jubileumsfond, Grant M13-0559:1, PI: Staffan I. Lindberg, V-Dem Institute, University of Gothenburg, Sweden; by Swedish Research Council, 2013.0166, PI: Staffan I. Lindberg, V-Dem Institute, University of Gothenburg, Sweden and Jan Teorell, Department of Political Science, Lund University, Sweden; by Knut and Alice Wallenberg Foundation to Wallenberg Academy Fellow Staffan I. Lindberg, V-Dem Institute, University of Gothenburg, Sweden; by University of Gothenburg, Grant E 2013/43.
} 


\begin{abstract}
This paper introduces the Core Civil Society Index (CCSI), a measure of the robustness of civil society, using indicators from the Varieties of Democracy battery on civil society. It begins with a discussion of the reemergence of civil society as a central concept in comparative politics and discusses the existing state of data to capture it. It then discusses the conceptualization behind the CCSI and the construction of the measure. This is followed by a series of face and discriminant validity checks. The paper closes with an example of the CCSI's utility by examining the question of whether postcommunist civil society is "weak" compared to other regions. We find no evidence that postcommunist civil society is less robust than civil society in other major world regions via time-series cross-sectional analysis using 2999 country-year observations between 1989 and 2012.
\end{abstract}




\section{Introduction}

This paper discusses the Varieties of Democracy (V-Dem) Core Civil Society Index (CCSI), an indicator meant to capture the robustness of civil society across a large number of states for the period 1900-2012. It begins with a discussion of the importance of civil society as a concept in comparative politics and the difficulty of testing general propositions about it due to the existing data environment. It then discusses the conceptualization and operationalization of the CCSI. With these basics established, it then performs a series of validity tests and demonstrates the utility of the measure by revisiting the debate on the strength of postcommunist civil society.

\section{The Emergence of Civil Society as a Key Concept in Comparative Politics}

Civil society has been an important concept in both political theory and the study of regimes and regime change in modern political science. It played a critical role in the conceptualization of modern society in the political thought of the Scottish Enlightenment (Ferguson 1767 [1995]) and German Idealism (Hegel 1820 [2001], Marx 1843 [1978]). It has also received a great deal of attention in contemporary critical theory (Cohen and Arato 1994, Keane 1998, Bobbio 1988). However, in many regards the notion of civil society that we employ in political science today has two parents, the Italian Marxist Antonio Gramsci (1971) and the French aristocrat Alexis de Tocqueville ([1820] 2004). From Gramsci we continue to think of civil society as a realm of contestation, where organized social actors challenge the power of the state and other social forces. From de Tocqueville we draw the notion that civil society is the very integument of democracy. Instead of stoking reactionary nightmares of democracy as mob rule, de Tocqueville explored how an engaged and organized citizenry enables more egalitarian, mass-based forms of rule.

In modern comparative politics civil society reemerged as a central concept of analysis in the 1980s to describe the reemergence of protest movements and underground organizations under authoritarian regimes. This analysis is neo-Gramscian in nature, in that it sees civil society as an emergent realm of contestation with dictatorship. This in turn led to retrospective understanding of similar phenomena in earlier historical epochs. ${ }^{1}$ What was novel about this approach was that civil society was posited to coexist with authoritarian regimes and that this held the potential to liberalize, if not democratize them. Among the earliest and most influential

\footnotetext{
${ }^{1}$ See the essays in Bermeo and Nord (2000).
} 
in this regard was Alfred Stepan $(1985,1988)$ who observed such development first hand in Brazil in the resistance to and liberalization of military dictatorship there. In Eastern Europe, Andrew Arato ([1981] 1993) made similar observations on the emergence of new oppositional social actors as the impetus for change in state socialist regimes. This observation was significant because the essence of the state-socialist project was the abolition of civil society (Kolakowski 1974).

With the third wave of democratization this neo-Gramscian notion of a contentious civil society came to be fully embraced by the discipline when it was integrated into influential actor-centered process models of democratic transition. O'Donnell and Schmitter refer to the response of social actors to new opportunities opened up by liberalization as "the exploding layers of society" $(1986,49)$. Such mobilization is a decisive factor in the extension of liberalization into democratic transition. Przeworski (1991) takes this even further, pinpointing whether civil society accepts the loosening of constraints on speech and organization inherent in liberalization or whether it presses for further concessions as the key juncture in democratic transition.

The neo-Toquevillian notion of civil society drew its inspiration from the study of mass political behavior and consideration of the forms of political culture most congruent with democratic rule. Important contributions were made early on by Almond and Verba (1963) who saw an expansive layer of activist citizenry as central to democracy. This line of reasoning was advanced by Putnam (1993) whose account of civic participation and government performance across Italy placed associational life at the center of the forms of social capital necessary for effective governance. And in a number of different iterations, Inglehardt and collaborators (e.g., Inglehardt and Welzel 2005, Welzel et al. 2006) have produced a wealth of studies that link a complex of values including citizen-level engagement with pro-democratic political cultures. While such foundational accounts of democratic political culture did not explicitly conceptualize this in terms of civil society, it has been recognized as such by others (Edwards and Foley 1999). While there has been widespread adoption and acceptance of neo-Gramscian notions of an "insurgent civil society" as a fundamental actor in contemporary democratization and a neoToquevillian notion of a "regularized civil society of social interests" as a critical sphere in durable democracy, there have also been a number of dissenting views. Several accounts raise the specter of an activist civil society as a means for authoritarian mass movements to overthrow democracy (Berman 1997, Chambers and Kopstein 2001, Riley 2010). Others have disputed the notion of cultural congruence with democracy, arguing that the causal relationship is inverted 
and that social trust and citizen engagement is less central to democratic success than theorized (Barry 1970, Seligson and Mueller 1994, Encarnación 2003, Rothstein 2005).

\section{The Existing Data Environment}

Data to measure civil society, until now, has been difficult to collect and apply in cross-national analysis. The discussion that follows introduces the extant indicators and their limitations for doing time-series, cross-sectional type analysis. This is in no way meant to diminish the importance of the work of these authors, their measures, or the analyses based on them.

The most common measurement of civil society uses questions from the World Values Survey (WVS) on organizational and protest behavior. WVS and the various regional surveys and attitudinal barometers it has inspired are a major resource in the study of political culture. The surveys have now been conducted for over thirty years in six waves and have included as many as 50-60 countries in individual waves (World Values Survey 2013). However, the WVS is only repeated every five years due to resource constraints, alternates two different questions on organizational behavior, and does not always include the same countries, posing major challenges for studying civil society in any sort of panel or country-year set-up for a global sample.

Event history coding of protest is also an important means to study the development of civil societies in a small number of contexts over time. Such coding is very difficult and expensive to replicate over a large number of countries. The most extensive, ambitious, and sustained project of this sort has compiled annual data for four countries over a thirty year period. $^{2}$ Some have also examined the registration of new organizations from statistical annuals or registries on a national level but these figures are limited in that they do not track exit or activism, and are hard to collect in comparable terms across countries (Ekiert and Foa 2012, Fernandes and Branco 2013).

Several organizations have tried to remedy these problems by measuring different components across civil societies. One of the most ambitious is the Civicus Civil Society Index which looks at civil society in fifty to sixty different countries since 1993. Its famous diamond consists of four different dimensions, "the organisational structure of civil society, civic engagement, perception of impact, practice of values and the enabling environment" (Civicus 2012). The most recent Civicus CSI round covered 35 countries for the period 2008-11 (Civicus

\footnotetext{
2 The Logic of Civil Society in New Democracies project continues the coding pioneered by Ekiert and Kubik in their original study on East Central Europe. The expanded study relies on extensive teams of researchers in Hungary, Poland, South Korea and Taiwan. See Ekiert and Jan Kubik (1999), Ekiert, Kubik, and Wentzel (2014).
} 
2011). Work on this measure has been suspended and has been replaced by the Civicus Civil Society Enabling Environment Index or EEI (Civicus 2013).

The EEI measures the "conditions that impact on the capacity of citizens... to participate and engage in the civil society arena in a sustained and voluntary manner." The first report issued in 2013 includes 108 countries. The measure is composed of 53 indicators compiled over the period from 2005-2012, which capture three major dimensions (socioeconomic, socio-cultural, and governance) broken into 17 sub-dimensions. While very ambitious in scope and useful for policy-makers and activists, this measure, by its nature, is very hard to use in statistical analysis except in basic cross-sectional terms (Civicus 2013).

The Center for the Study of Global Governance at the London School of Economics has compiled a Global Civil Society Index. In 2002 they published rankings for 33 countries in Europe and the Americas circa 2000 (Anheier and Stares 2002). To complicate things there is also a second Global Civil Society Index compiled by the Center for Civil Society Studies at Johns Hopkins University. This index initially only covered sixteen countries around 2000 (Center for Civil Society Studies 2004). Disaggregated components were compiled for thirty six countries in an updated version (Salamon, Sokolowski, and Associates 2004, chapter 2).

USAID has developed a Civil Society Organization Sustainability Index (CSOSI). It examines four to six dimensions in any given year including the legal environment, organizational capacity, financial viability, advocacy, service provision, infrastructure, and public image and ranks them on a scale of 1-5. The CSOSI is an average of the components. They have compiled the index for postcommunist Europe for the years 1997-2011 and for twenty countries in Sub-Saharan Africa in 2009-2011 (USAID 2012a, 2012b).

Freedom House's Nations in Transit series (2012) also calculates a civil society score for the postcommunist countries. It ranks civil society on a scale from one to seven based on nine open-ended questions answered by experts. The ranking on the scale is originally determined by the author of the expert report and is then reviewed by outside readers and a board of academic advisors. Rankings are available for 1995 and 1997-2013 (Freedom House 2012b).

The Bertelsman Transformation Index produces 49 scalar measures using expert opinion which are then compiled into a series of indices which gauge the extent to which the countries in question have transformed into liberal democratic market systems. After a pilot study in 2003 it has been compiled biennially since 2006 for 129 developing and transitional countries. It has four indicators relevant to the study of civil society - organizational freedom, the presence of interest group networks, social self-organization, and a civil society tradition (Bertelsmann Stifftung 2014, 122-127). 
Last but not least, the International Institute of Social Studies in The Hague has created a set of "Indicators of Social Development" (ISD) that measure aspects of civil society. They have compiled a civic participation indicator for 209 countries at five year intervals from 1990 to 2010. Seventeen percent of the observations are missing. It is compiled from a variety of answers to values and attitudes surveys, data on international non-governmental organizations, the Civicus CSI, and data on communications technology (Institute of Social Studies 2015a). The coverage of the sub-indicators are subject to a higher degree of missingness than the indicator itself. This problem is addressed through the use of percentile matching techniques rather than imputation (Foa and Tanner 2012). They have also compiled an indicator of "clubs and associations" from values and attitudes surveys. It is subject to a very high degree of missing observations - fifty-five percent (Institute of Social Studies 2015b).

\section{The Conceptualization behind V-Dem's Civil Society Battery}

We conceived of civil society as an essential intermediary sphere of the polity. It lies in the public space between the private sphere and the official sphere of the state. It is not the only set of actors that lie within the non-official public sphere - it shares this space with political society, a set of public actors who are consciously organized to contest the control of state power. While civil society has a degree of autonomy from the state (ranging from extensive to minimal), civil society is still regulated by the state. The state establishes a framework for the operation of civil society, and often intervenes in its life (though the degree of freedom of civil society is enhanced by less intervention). ${ }^{3}$

Civil society is populated by groups of citizens organized to act in pursuit of their interests broadly conceived. This would include both material interests (goal-oriented, Zweckerational in Weberian terms) and interests inspired by values (Wertrational) (Weber 1978, 25). We refer to these groups of self-organized interested citizens as civil society organizations (CSOs). CSOs include, but are by no means limited to, interest groups, labor unions, religiously inspired organizations (if they are engaged in civic or political activities), social movements, professional associations, charities, and other non-governmental organizations.

It is essential to distinguish between the public and private spheres in understanding what constitutes a civil society organization. Both routine spiritual and economic activity are not civic but private. The productive activity of firms is not part of civil society, nor is the spiritual

\footnotetext{
${ }^{3}$ Foundational works on the understanding of civil society from the structural perspective employed here include Arato ([1981] 1993) and Stepan (1985). See also Bernhard (1993, chapter 1). Linz and Stepan (1996) provides further elaboration of this structural perspective.
} 
activity housed in religious institutions. However, when producers, workers, or people who share a set of spiritually grounded political, moral or ethical beliefs organize on the basis of a shared set of interests and pursue their realization in the public space, such activity is assuredly part of civil society.

The existence of civil society is a necessary but not sufficient condition for democracy. This means that civil society is compatible with both authoritarian and democratic political systems. Some forms of dictatorship, specifically those which enforce a monopoly on political and civil organization, are not compatible with civil society. However, such harsh political projects, the sorts of dictatorships that have inspired the label "totalitarian," as well as some forms of authoritarianism in their harsher phases, are less common than dictatorships that permit some level of civil society organization (Linz and Stepan 1996).

\section{The V-Dem Core Civil Society Index}

The V-Dem project has compiled almost 400 disaggregated indicators of democracy for 173 sovereign states and territories for the period 1900-2012. ${ }^{4}$ We aggregate these indicators to distinguish seven varieties of democracy - electoral, liberal, majoritarian, consensus, deliberative, egalitarian, and participatory (Coppedge et al. 2011, 2015a). Given the importance of civil society in recent theorizing about regimes and regime change and the difficulty in testing falsifiable hypotheses with a high degree of external validity, our aim was to produce both a series of disaggregated indicators that get at the different aspects of civil society as well as a general index of civil society robustness that covers a global sample of countries over an extensive period of time.

We use the in-depth knowledge embedded in responses from country experts to questions about fundamental characteristics of critical areas of democratic development for which it is difficult, prohibitively expensive, or impossible to collect observational data. In the process over 2,500 country experts worldwide have contributed ratings to V-Dem (Coppedge et al. 2015b, 2015c). The country-expert data is combined into country-year estimates using a stateof-the-art Bayesian ordinal item-response theory model developed by the project's methodologists (Pemstein et al. 2015). The V-Dem civil society battery has ten questions that gauge different disaggregated aspects of civil society. ${ }^{5}$ The full battery is available in the V-Dem

\footnotetext{
${ }^{4}$ For 60 countries, data is also available for 2013-2014. The public release of the data is scheduled for December 2015.

${ }^{5}$ In addition to the three questions used to compile the CCSI, which are discussed in depth below, we asked questions on civil society consultation, organizational characteristics, and whether particular groups are subject to
} 
Codebook (Coppedge et al. 2015a, 238-247). The answers to three of the questions have been aggregated into a general measure of the robustness of civil society called the Core Civil Society Index (CCSI, v2xcs_ccsi).

One can think of civil society strength in terms of its ability to organize free of state constraints and how engaged the citizenry is in CSOs. We aggregate three of our indicators designed to this end to construct the CCSI, which allows us to distinguish robust from feeble civil societies. ${ }^{6}$ Figure 1 below maps the conceptual thinking behind the index.

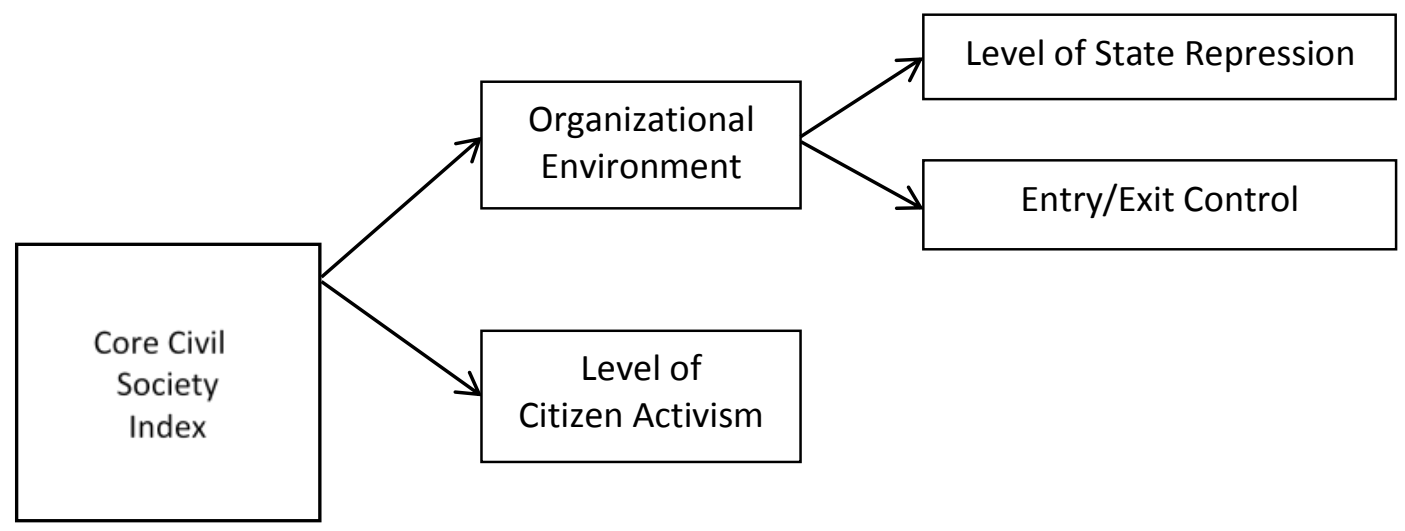

Figure 1: Conceptual Mapping of the Core Civil Society Index (CCSI)

State constraints on civil society come via two different mechanisms. States may use the law to regulate the entry and exit of CSOs into the public space. The law often serves as a means to determine who can organize and who cannot. A second mechanism is direct repression of organizations and activists, another common practice in many countries in many times. These two in combination with each other can be thought of as the organizational environment created by the state for civil society.

We capture these mechanisms using two questions from the civil society battery. The first concerns the control of CSO entry and exit by the state (v2cseeorgs). The experts were asked to assess state control of CSO entry and exit on a five point scale from 0 to 4 with zero representing monopolistic control by the state authorities to 4 representing a lack of constraint. The second question concerned the level of state repression of CSOs (v2csreprss). Here the

discrimination in civil society. Another important dimension we tried to capture is whether civil society contains anti-system movements and their character.

${ }^{6}$ They are also available in disaggregated form in the dataset, and there is no reason why they cannot be used in a disaggregated fashion or aggregated into measures to capture other concepts. 
responses ran from zero to four with zero indicating active repression by the state to liquidate CSOs and four indicating substantively no government repression or harassment of CSOs.

The degree of citizen involvement in CSOs is gauged by a third question on the participatory environment in civil society (v2csprtcpt). The experts were asked to rate individual country-years from zero to three, with zero capturing situations in which the state sponsors all organizations, thus effectively exercising a monopoly on organization as in many state socialist and state corporatist regimes. Its maximum value is three for those societies in which there are many diverse CSOs and citizens are at least occasionally active in them. The full codings including the intermediate rankings for all three questions used in the CCSI are available in Coppedge et al. (2015a, 240-243).

\section{Creating the V-Dem Core Civil Society Index}

Up until this point the paper has discussed the importance of civil society as a concept of central importance in the study of democracy and democratization, and how a subset of questions from the V-Dem civil society battery can be used to capture the concept of civil society robustness. We now explain how we created the CCSI to serve the needs of researchers looking for a single convenient indicator that captures the relative strength of civil society across observations. By robustness we mean that civil society is able to establish autonomy from the control of the state and that citizens pursue their collective interests actively. After our discussion of how the measure was constructed, we then perform a range of validity tests. We end the paper by applying the measure to a question derived from an ongoing debate on the nature of postcommunist civil society.

The construction of the CCSI can be broadly thought of as a two-step aggregation process. In the first stage, ordinal ratings provided by multiple country experts for the relevant variables are aggregated by utilizing Bayesian measurement models. In the second stage, the output of these statistical models is aggregated into the CCSI using Bayesian factor analysis techniques. We briefly review each stage.

Since country experts provided multiple ordinal ratings for each of the variables that constitute the $\mathrm{CCSI}^{7}$ the first measurement challenge is to aggregate the ordinal ratings into a unified, continuous and reliable variable. Individual raters might vary with regard to the way they interpret the questions, and in terms of reliability and consistency. Thus, we utilize Bayesian item response theory models to aggregate their diverse ratings. These models are useful because they

\footnotetext{
${ }^{7}$ The average numbers of country coders for the variables are 5.15 for v2cseeorgs, 5.05 for v2csprtcpt, and 5.11 for v2csreprss.
} 
incorporate the information encoded in the variation in raters' perceptions, and in reliability levels across and within coders into the estimation process (Bollen and Paxton 2000, Jackman 2004). While this type of model has been widely used in political science to measure legislators' ideology based on binary data (e.g. Clinton et al. 2004), their use to systematically aggregate multi-rater ordinal data is much less common (cf. Pemstein et al. 2010, Schnakenberg and Farris 2014).

The main assumption underlying item response theory is that the variable being measured is latent, i.e. cannot be measured directly, and that raters perceive the true value of the variable with some error. Importantly, the model utilizes coder ratings and patterns of disagreement across raters to estimate coder level errors, and down weighs the ratings provided by coders who are deemed less informative with regard to the latent variable. By utilizing a Bayesian modeling framework, we are able to estimate the country-year latent quantity of interest (e.g. the latent degree to which CSOs are harassed by the state in Spain in 1974), as well as simultaneously estimate the thresholds that separate the levels of the latent variable. Put differently, the model estimates country-year level parameters that capture the latent variable of interest, along with thresholds differentiating the various levels of this latent variable. ${ }^{8}$

Expert surveys pose a problem for social scientists in terms of cross-national comparability. Coders who vary in terms of their educational and cultural backgrounds might have different perceptions of the latent variable, and may, in addition, have different latent thresholds (King and Wand 2006). If these coders provide ratings for disjointed units, model estimates will be problematic since estimates for different countries will be based on different scales. In order to mitigate this problem, the V-Dem project has recruited a large number of bridge-coders, i.e. coders who serve as connecting units across previously disjointed countries. Extensive Monte Carlo simulations provide strong evidence that bridge coders indeed improve model fit and greatly increase the degree of cross-national comparability (Pemstein et al. 2015).

In the second stage of the index construction, we generate the CCSI scores using Bayesian factor analysis. As before, utilizing the Bayesian framework is advantageous since it allows us to generate uncertainty estimates for the index. As can be seen by the results in Table 1, all three variables load highly on the latent dimension (CCSI).

\footnotetext{
8 Since we are using a Bayesian framework, the model provides full posterior distributions for each parameter. Our point estimates are the means of these distributions. In addition, we leverage a hierarchical structure in which we estimate coder specific thresholds (also known as difficulty parameters in the psychometric literature), and cluster these around country-level thresholds, which are based on the country for which a given rate has provided the longest time series. In turn, these country-level thresholds are modeled as random deviations from global, variable level thresholds.

${ }^{9}$ Using the rstan library in R, we ran all models for 500 iterations, with a burn-in period of 1000 iterations. All standard diagnostics tests suggested model convergence.
} 
Table 1: Factor Analysis Scores for CCSI Components

\begin{tabular}{ccc} 
Variable & Loading & Uniqueness \\
\hline v2cseeorgs & 0.96 & 0.07 \\
v2csreprss & 0.88 & 0.21 \\
v2csprtcpt & 0.82 & 0.31
\end{tabular}

\section{Validity Checks}

We ran a series of validity checks to increase our confidence in the data. In the paper we present a series of macro- and micro-level face validity checks. We also present a series of discriminant validity checks using existing datasets, as well as a series of convergent validity tests.

Macro-level Face Validity

In thinking about how to assure ourselves that the data generation process yielded a valid indicator, we designed several basic tests that examined whether CCSI behaved in conjunction with our expectations over large units of time and space. The first concerns how we expected the CCSI to develop over time. Our expectations were that civil society would be considerably weaker in the earliest part of the century, that it would drop off during waves of concentrated failure of democratic regimes and installation of harsh dictatorship (e.g. the heyday of totalitarianism and total war in the 1930s and 1940s and the wave of bureaucratic authoritarianism that hit Latin America in the late 1960s and early 1970s) and that it would grow extensively with the Third Wave of democratization that led to the reembrace of the concept by the discipline. ${ }^{10}$ We examine this in figure 2 below.

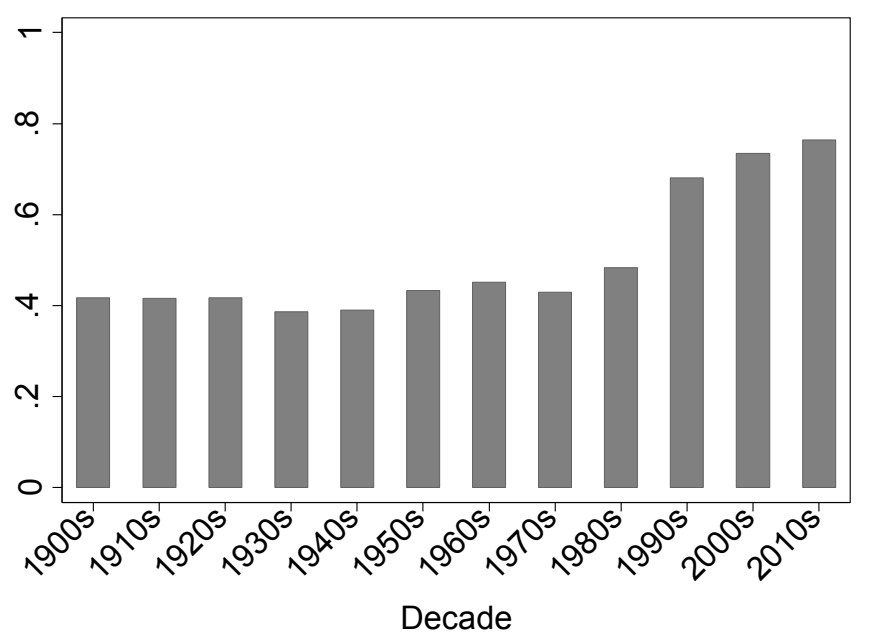

\footnotetext{
10 The descriptive analyses in this section include both sovereign states and colonial dependencies.
} 


\section{Figure 2: Mean CCSI by Decade}

The figure plots the mean CCSI by decade over the course of the data from 19002012. ${ }^{11}$ As we expect the level of civil society development is lower at the beginning of the twentieth century than it is today. As expected it hits its low point in the 1930s and 1940s. It recovers and grows in the 1950s and 1960s and then experiences a downturn in the 1970s just before the full onset of the Third Wave. With the global expansion of democracy that follows we see civil society growing in strength globally from the 1980s until the present day.

We also have strong expectations about how civil society strength should vary geographically. Those regions which have had sustained histories of development, competitive politics, and political pluralism should have the strongest civil societies. Thus we expect from a historical point of view for strong civil societies to be prevalent in places like North America and Western Europe compared to other regions of the world. In regions in which there are long histories of harsh dictatorship, we would expect to see weaker civil societies over time. In figure 3 below we show the mean country-year CCSI scores for the major geographic regions of the world. ${ }^{12}$

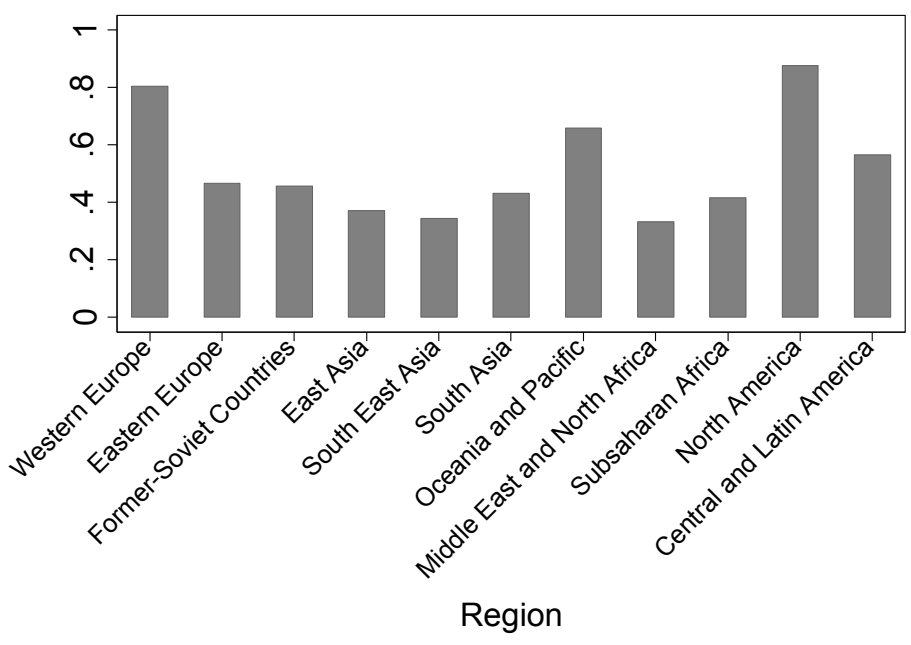

Figure 3: Mean CCSI by Region (1900-2012)

\footnotetext{
11 All analysis in this paper was done using version 4.2 of the V-Dem dataset, truncated to 2012 because of the partial nature of the updates for 2013 and 2014 (Coppedge et al., 2015b).

12 For the regional categories used for these plots, we modified the V-Dem codings (Coppedge et al. 2015d). The Nordic countries and Southern and Western Europe are combined into Western Europe. The countries in the Balkans and East-Central Europe are merged into Eastern Europe except for Belarus, Latvia, Lithuania, Moldova, Russia, and Ukraine, which are categorized as Former-Soviet countries with all countries in the Caucasus and Central Asia (except for Afghanistan which we included in South Asia). Central Africa, East/Horn of Africa, Southern Africa, and West Africa are combined into Sub-Saharan Africa. The Caribbean, Central and South America are combined under Latin America. The remaining regions - East Asia, Southeast Asia, South Asia, Oceania, Middle East/North Africa, and North America - followed the V-Dem categorization.
} 
Here again the picture presented by the data has strong face validity. The most robust regions for civil society are Western Europe and North America. Oceania, where the neo-Englands of Australia and New Zealand, constitute a large part of the sample, is also above the mean as well. Latin America with its history of fluctuation between competitive and authoritarian regimes falls somewhat in the middle. The remaining regions of the world, where most countries spent the bulk of the twentieth century either under sultanistic or (post)totalitarian regimes have had much less robust civil societies across the sample.

Figure 4 further examines the regions, but looks at them over time. These plots give us further confidence in the face validity of the data in that they are congruent with historical events that have important ramifications for the development of civil society in those regions. 

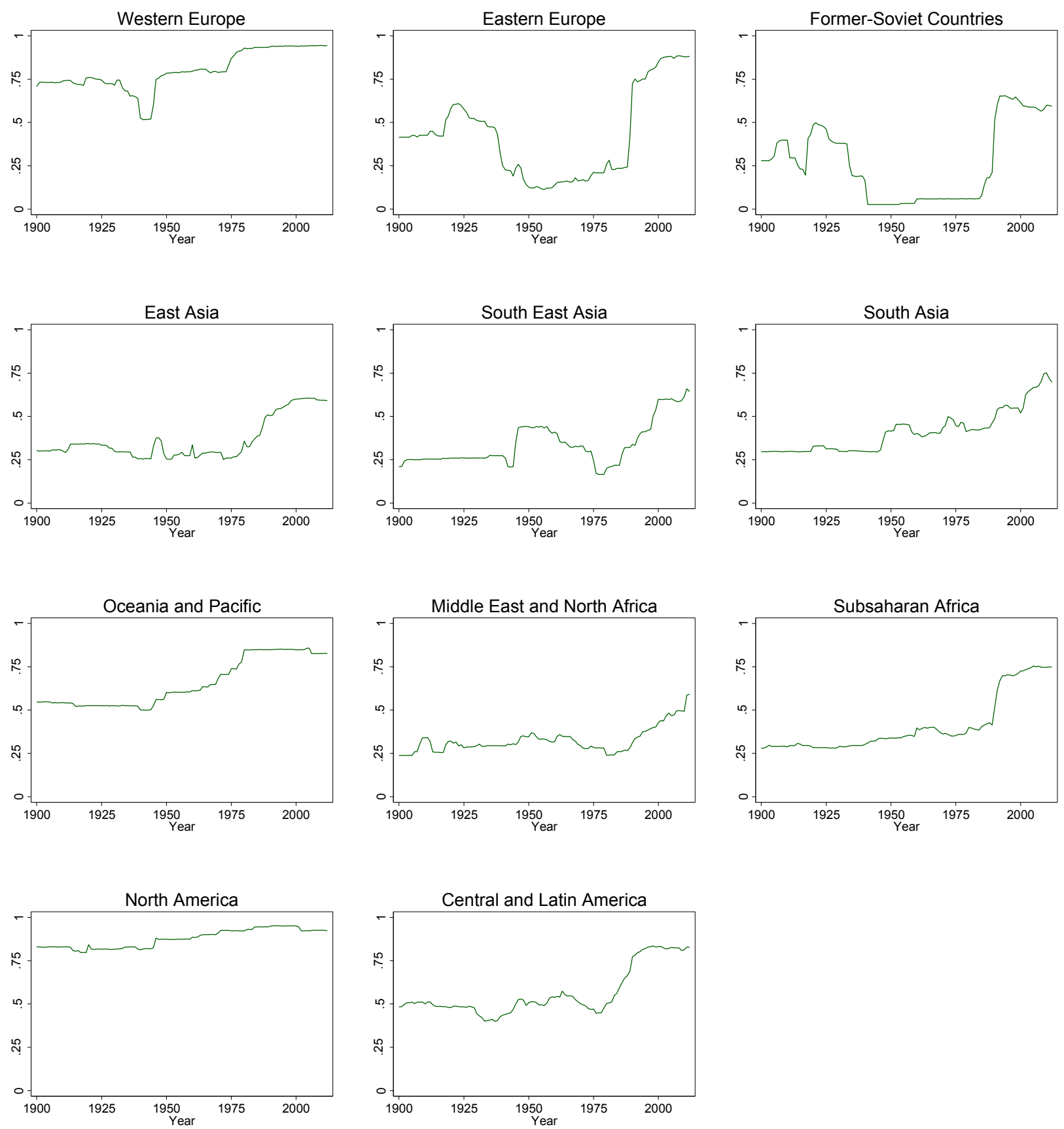

Figure 4: CCSI by Region over Time

Again the patterns for the regions over time are congruent with the sort of variation we would expect to see in line with historical events. The CCSI in North America is very stable over the whole range. In Western Europe we see a high level generally but during the period of fascism and war in the thirties and forties we see a precipitous drop off. In Eastern Europe we see a brief flowering in the early part of the interwar era when many countries achieved independence and experimented with pluralistic regimes. The level of CCSI then drops to very 
low levels during communist rule around 1950. It then grows to high levels in the period after the annus mirabilis of 1989. For the former Soviet Union, we see a drop from the period of the Revolution of 1917 to the installation of Stalinism in the late 1920s where it stays at a very low level until the advent of perestroika in the 1980s. Since then it has remained at a fairly moderate level reflecting a mix of different regimes (democracies in the Baltic states, competitive authoritarian regimes in other European successor states, and conventional authoritarian regimes in Central Asia).

In the developing world, we see the marked effect of the third wave of democratization and relaxation of restrictions on civil society both in Latin America and Africa. In Asia there is general upward movement in all three regions, but the higher degree of dictatorship there keeps the overall level moderate rather than high. The CCSI is lowest in the Middle East and North Africa, but here too we see upward movement as of late, reflecting the liberalization and protest movements of the Arab Spring.

\section{Micro-level Face Validity}

Another means to establish the face validity of the data is to examine the extent to which the CCSI is congruent with the historical development of civil society in particular countries. We should observe change over time in line with particular events related to the constraints on CSOs and levels of mobilization. We chose to examine Venezuela, Ghana, and Russia based on the area expertise of team members.

Venezuela's CCSI for the period 1900-2012 is displayed in Figure 5 below. It also includes the ninety percent confidence intervals generated by the measurement model. The variation over time corresponds to three important periods. Before 1935, the country knew only military dictatorship, and civil society was tightly circumscribed. When General Gómez died in 1935, a series of transitional governments oversaw political liberalization, especially the growth of unions and political parties. This culminated in the Trienio of 1945-48, considered by many to be Venezuela's first attempt at democracy. This period saw the rapid organization of peasant leagues and the expansion of professional associations. It was quashed by a military coup in 1948, leading the political opposition to go underground or into exile until a durable transition to democracy in 1958-59. This led to a period of great freedom for all sorts of civil society organizations, although they were heavily politicized along partisan lines. 


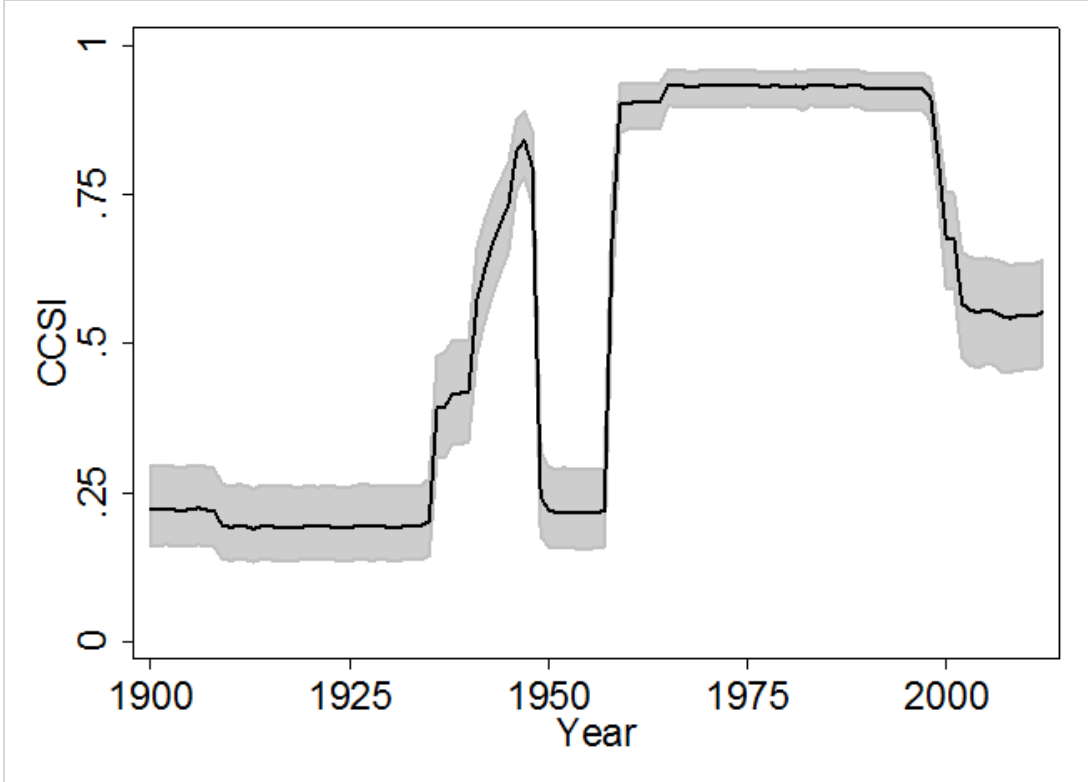

Figure 5: The Development of Civil Society in Venezuela, 1900-2012

The recent sharp decline corresponds to the government of Hugo Chávez Frías (19992013). CCSI helps to illuminate this controversial period. Although this government repeatedly won elections and survived most referendums, civil society experienced many setbacks due to threats against union leaders, arrests of opposition politicians and judges, intimidation and harassment of NGOs and public employees, monitoring of political loyalties by governing-party officials and neighborhood activists, and progressive muffling of critical viewpoints in the media. Most of the change in CCSI for Venezuela was due to two components: government attempts to repress CSOs (v2csreprss) and "moderate" government control over the entry and exit of CSOs into public life (v2cseeorgs). The CSO participatory environment variable (v2csprtcpt) remained at the same level from 1959 to 2012: "There are many diverse CSOs, but popular involvement is minimal." Venezuela saw growing CSO independence from parties in the early 1990s and sporadic mass mobilizations in the 2000s, but not much strengthening of civil society organizations in this last period.

Figure 6 presents Ghana's CCSI over time. In the early twentieth century under British colonial rule, the moderate CCSI scores reflect that civil society organizations existed and operated with minimal interference as long as they did not challenge British rule. To that end the colonial authorities exercised a fair degree of control over which organizations were allowed to exist but otherwise were not unduly repressive nor did they particularly discourage participation in CSOs. The upward movement in the CCSI starting after World War II reflects an upsurge in 
activism due to the emergence of a broad-based national independence movement that succeeded in 1957.

Soon after independence the new government under Kwame Nkrumah and the Convention People's Party (CPP) called for national unity over pluralism and CSOs were subjected to increased levels of repression, including the infamous Preventive Detention Act in 1958 that gave the prime minister the power to detain individuals for up to five years without trial. Nkrumah, who was later declared president for life, tolerated no further political competition, and as Ghana became increasingly autocratic, civil society had less room to maneuver than even under colonial rule. This explains the sharp drop in the CCSI following independence.

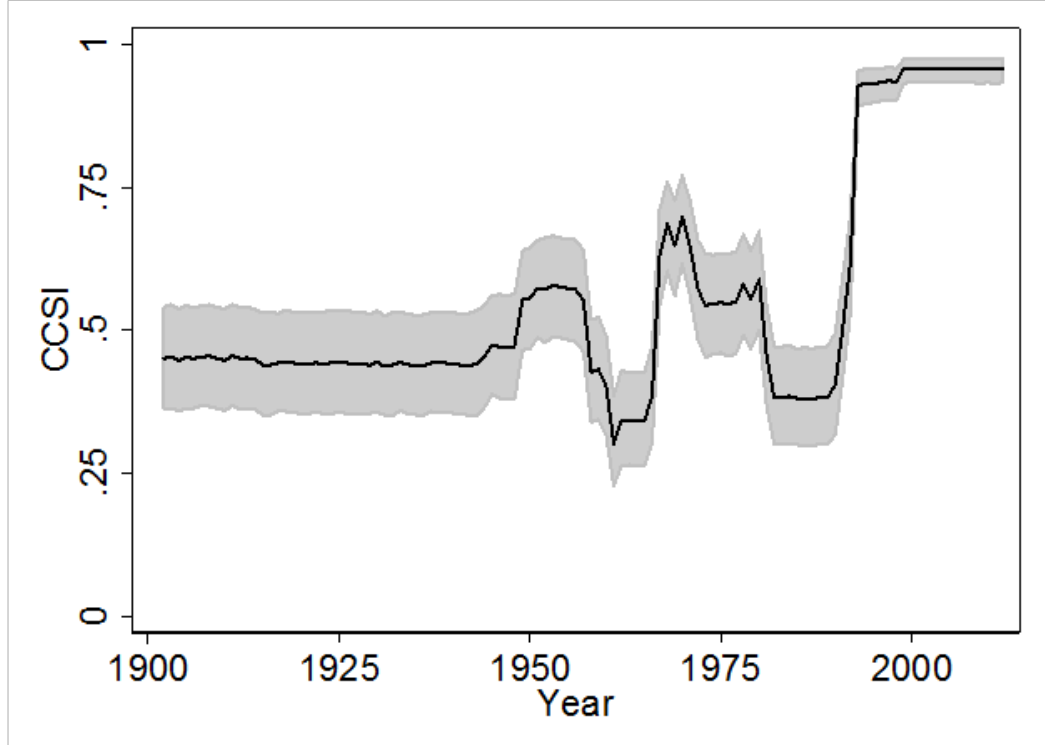

Figure 6: The Development of Civil Society in Ghana, 1900-2012

We observe a positive change in the CCSI in 1967 following the military coup that overthrew Nkrumah in 1966, when the National Liberation Council took over and liberalized in anticipation of elections in 1969. This period of liberalization and fledgling democracy was terminated by another coup led by Lieutenant Colonel I. K. Acheampong in 1972. Continued stagnation and political gridlock led to two additional military coups led by Flight Lieutenant J. J. Rawlings in 1979 and 1981. Following the latter, Rawlings ushered in a longer period of nationalist-socialist rule by the Provincial National Defense Council (PNDC). The CCSI accurately captures this period when the Rawlings regime actively repressed CSOS and imposed tight controls on their entry and exit.

The CCSI grows rapidly starting in 1988-89 when the Rawlings regime opened up political and civilian space and elections to local district assemblies were rolled out. By 1991, 
protests and demonstrations were allowed more or less freely in Ghana, and civil society no longer feared repression from the Rawlings regime. The CCSI reflects this rapid improvement that came with democratization in 1988 to 1992. Since then it has remained at high levels under Ghana's new period of democratic stability.

The CCSI for Russia (Tsarist, Soviet, and postcommunist) in presented in Figure 7. At the onset of the last century Tsarist Russia had a weakly developed civil society (reflected in a moderately low CCSI score) that left some latitude for organization by the nobility, the propertied, and professionals while denying it to workers, peasants, and minority nationalities. The CSSI improves slightly after the revolution of 1905 when a new constitution liberalized the rights of citizens to assemble and form associations. It then drops precipitously with the Revolution and Civil War period (1917-1921), when politics was highly chaotic and armed force ruled the day.

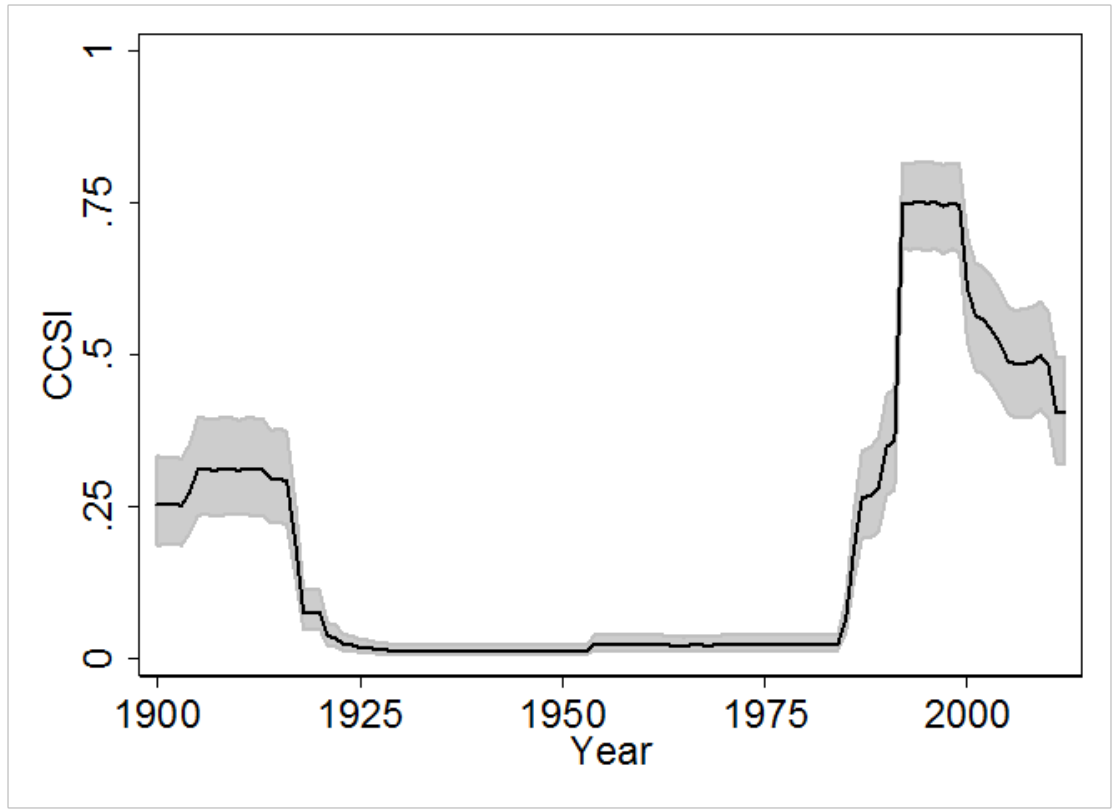

Figure 7: The Development of Civil Society in Russia, 1900-2012

The institutionalization of Soviet rule in the 1920s kept the CCSI at very low levels for an extended period of time. Under the USSR, society was subjected to extensive etatization with the citizenry firmly under the control of state sponsored transmission belt organizations. Beginning with the liberalization period of Glasnost and Perestroika under Gorbachev we see a sharp upturn in the CCSI due to a relaxation of state repression and control over the organizational realm. This period saw an upsurge in independent organizations, a marked increase in public demonstrations, protests, strikes and the like, and a relaxation of controls on public discourse. 
The upward trend continues after 1991 as the strength of civil society in Russia continued to grow in the period following the collapse of the Soviet Union and the onset of Yeltsin's rule, stabilizing at its maximum level throughout the 1990s. The decline beginning in 2000 corresponds to Putin's rule and his installation of a competitive authoritarian regime in Russia in which civil society activity was increasingly subjected to the heavy hand of the state anew, but at levels not nearly as harsh as under Soviet rule.

\section{Discriminant Validity Tests}

We also checked the correlations between the extant cross-national measurements of civil society against the CCSI and its components. Most of these measures are available for only a very small subset of the country years covered by V-Dem. The best coverage for an aggregate measure was provided by the USAID CSO sustainability data (2012a and 2012b) for postcommunist Europe and sub-Saharan Africa. Still the number of overlapping observations was relatively small $(\mathrm{n}=467)$. The correlation between CCSI with the USAID CSO sustainability index is $0.6781(\mathrm{p}<.001)$.

We also examined the correlations between the subcomponents of the CCSI and extant measures that might proxy for them. For our civil society repression component we ran a correlation with CIRI Physical Integrity Right Index, which captures the extent to which the population of a state is subjected to extrajudicial killing, torture, disappearances, and political imprisonment (Cingerelli, Richards, and Clay 2014). There is an overlap of over 4000 country year observations from 1981-2011. The fit between the two measures is not perfect, given that our repression index includes a number of lesser forms of harassment of CSOs and activists. The correlation between the two was $.5664(\mathrm{p}<.001)$. For our indicator on the freedom of CSO entry and exit we used the Freedom of Assembly and Association index, also from CIRI. Here the correlation was .6930 ( $\mathrm{p}<.001)$. The results for the Bertelsmann question on freedom of assembly and association (360 observations from 2006-2010) showed an even higher correlation -- .8160 (p<.001) (Bertelsmann Stiftung 2014a).

For the participation component we examined the relationship between the ISD Participation Index (Institute of Social Studies 2015a). Their scores cover half-decades from 1990-2010 and we correlated these with our corresponding country year observations for the nominal year of their observations. Given that their data are compiled over five year periods, we would again expect the correlation to be weaker than if we were making country-year to countryyear comparisons. Still the correlation was .5082 ( $\mathrm{p}<.001)$. 


\section{Convergent V alidity Tests}

In examining how the CCSI is correlated with other measures, we moved beyond discriminant validity, and also examined convergent validity, or the degree to which the CCSI is related to concepts that we expect to correlate with aspects of civil society. To do this, we first examined the association between the CCSI and V-Dem's thick index of freedom of expression. ${ }^{13}$ Our expectation is that a stronger civil society and free expression should be strongly correlated. We abstain from making claims about whether one causes the other, that they are mutually constitutive, or that they are caused by an unnamed set of other factors. Figure 8 presents the global mean by country year.

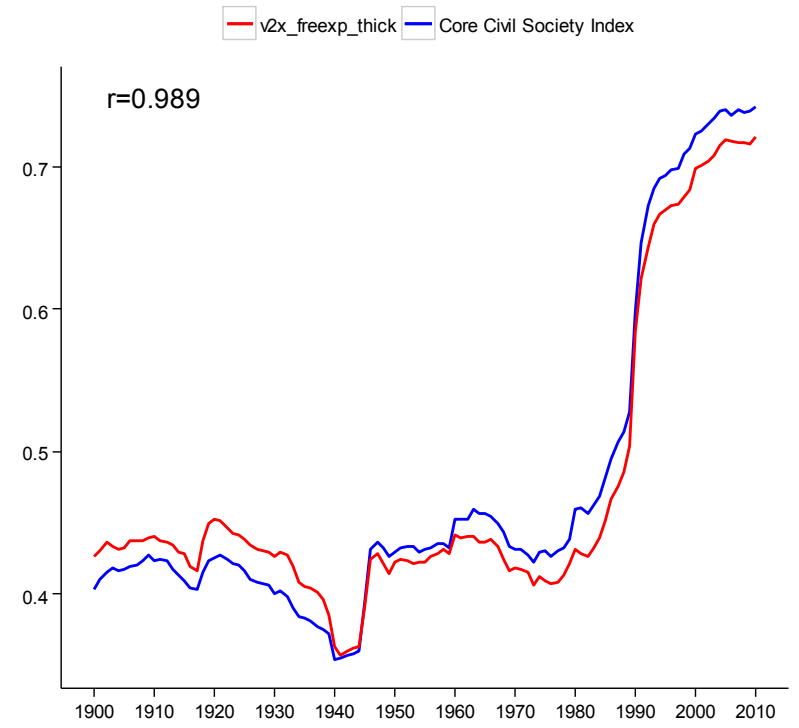

Figure 8: Association between CCSI and the Thick Freedom of Expression Index, 19002010

As can be seen, the two measures follow each other very closely, with a Pearson's correlation of 0.989. We also examined the degree to which these two indices co-vary across regions, and present these results in figure 9. Here too the results are very suggestive of our expectation on the relationship between the two variables.

\footnotetext{
13 This index is composed of the scores of a one-dimensional Bayesian factor analysis of nine V-Dem indicators that capture dimensions of free expression (print/broadcast censorship, Internet censorship, harassment of journalists, media bias, media self-censorship, print/broadcast media critical, print/broadcast media perspectives, freedom of discussion for men/women, and freedom of academic and cultural expression). See Coppedge et al. (2015a, 35-6).
} 
Western Europe

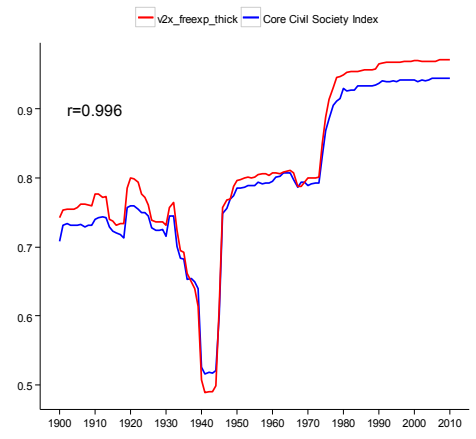

East Asia

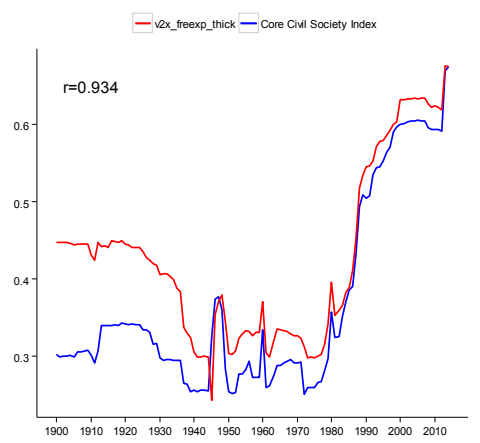

Oceania and the Pacific

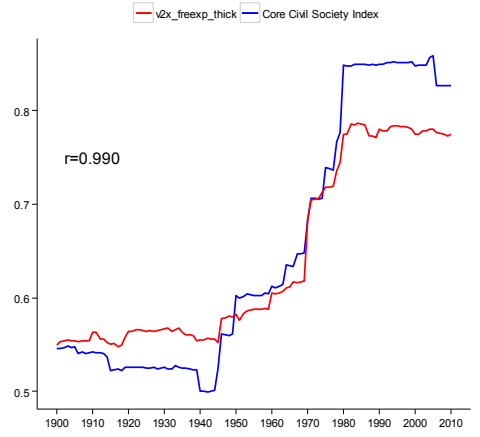

North America

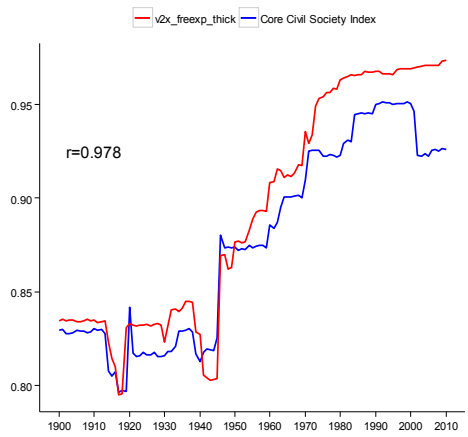

Eastern Europe

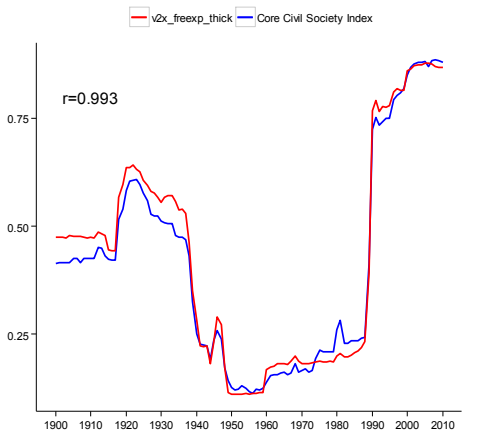

South-East Asia

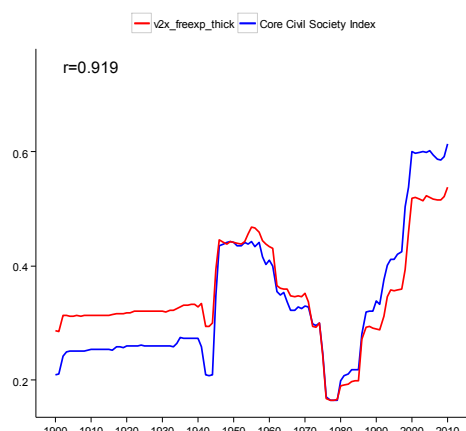

Middle East and North Africa

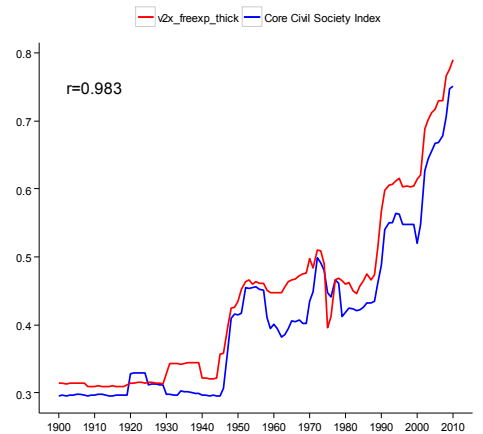

Sub-Saharan Africa
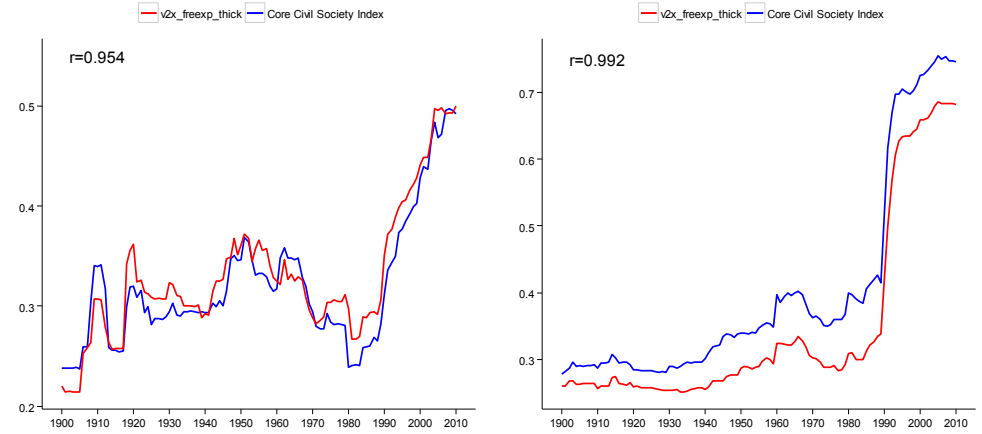

Central and Latin America

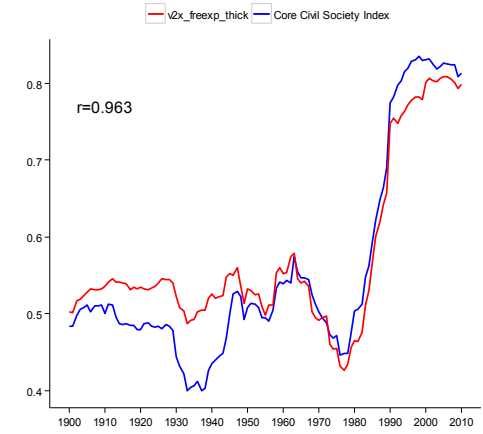

Figure 9: CCSI and Press Freedom, Regional Averages, 1900-2010 
We also examined the covariation of CCSI with another indicator from the V-Dem civil society battery that captures the extent to which anti-system movements, which might present a threat to the regime, exist. We present the result in figure 10. Our expectation is that more open polities, which have robust civil societies that can represent a broad range of interests, will be less likely to give rise to anti-system movements. As expected, we find a significant, yet not strong, negative correlation between the two. The relationship seems to be strongest since 1980 where the flowering of civil society globally coincides with a downward trend in anti-system movements.

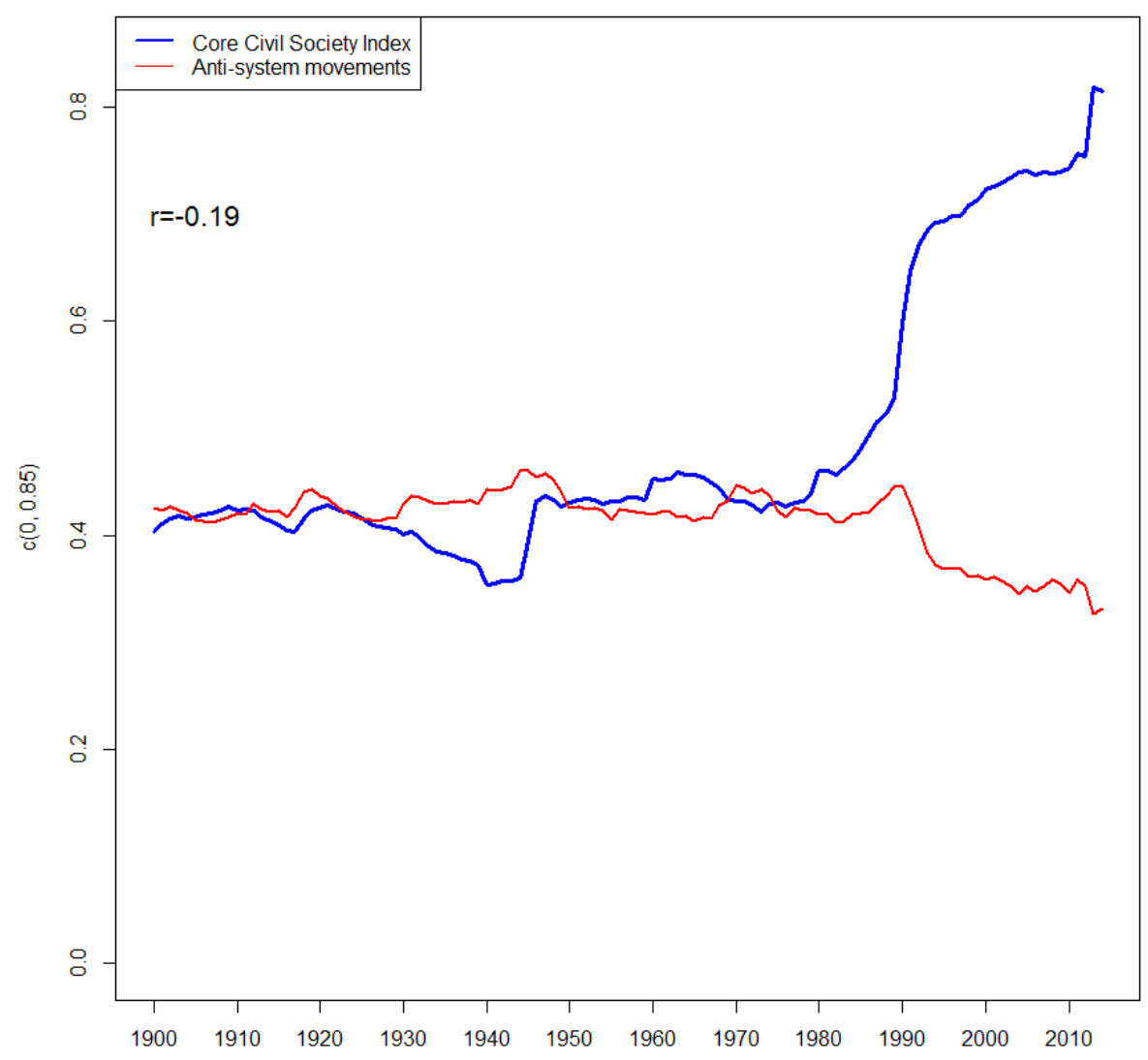

Figure 10: CCSI and Anti-System Movements, 1900-2010 


\section{An Example of How the CCSI Can Contribute to Substantive Debates: Civil Society Weakness in Postcommunist Europe}

Among those who agree on the relationship between civil society and democracy, there can be disagreements over the condition of civil society, and what this ultimately means for the fate of democracy. This is particularly manifest in the discussion of democratization in postcommunist Eastern and Central Europe. On the one side there are a group of observers who see post-communist civil society as relatively weak compared to civil society in other regions (Bernhard 1996, Howard 2003, Bernhard and Karakoc 2007, Pop-Eleches and Tucker 2013), and those who argue that the extant ways of measuring civil society through values and attitudes surveys miss parts of the picture, notably a vibrant development of civil society in the period since 1989 (Ekiert and Kubik 1996, Ekiert and Foa 2012). Instead they pose an alternative measurement strategy based on directly observable indicators such as protest event coding and the registry of new CSOs by the state.

Thus while there is good substantive justification to be concerned about the status of civil society among those interested in the study of democracy and its fate, the post-communist civil society debate points out the difficulties of coming to definitive answers because of the relative paucity of data. In one sense the two sides of this debate have been talking past each other due to radically different data sources. The findings that civil society is relatively weak is based on behavioral data drawn from the answers to questions on organizational joining behavior and propensity to protest drawn from global and regional value surveys and barometers. The contradictory position comes from event data coded from newspapers or statistical office figures on new CSO registration. Rather than reiterate the potential pitfalls of both forms of data, we will examine what CCSI says about the relative strength of civil society in various regions.

The descriptive data that we have presented above confirms the picture in the behavioral literature. In figures 3, the levels of the CCSI for Eastern Europe and the Former Soviet Union are considerably lower than that of the regions that have had a longer history of democracy. Still, this is not an entirely fair comparison when those other regions have had democracy for a much longer time. In figure 4 where regional levels of the CCSI are compared over time, the picture is somewhat different. In the period after 1989 the levels of both regions increases dramatically. While the levels of the post-Soviet states are still considerably lower than many regions, those in Eastern Europe (the countries of the former Soviet bloc) are higher than all except for Western Europe and North America. It is higher than that of Latin America, a 
region that has also experienced widespread democratization in the most recent historical epic, as well as the other regions plotted.

In the tests that follow we estimate the level of CCSI taking into account regional location as well as two factors thought to affect how strong civil society is. The first of these is the existence of democracy itself and the second is the level of development. In Table 2 we estimate the strength of civil society based on the level of development, ${ }^{14}$ level of democracy and a series of regional dummies. ${ }^{15}$ In controlling for democracy it is essential to use a measure that does not explicitly use elements that might well be captured by the CCSI as well, such as freedom of association. For that reason our controls embody minimalist measures of democracy. In this regression, we use the V-Dem Clean Elections Index (v2xel_frefair), which captures the extent that elections are free and fair and procedurally sound. ${ }^{16}$ We believe that this measure proxies well for Schumpeter's minimal electoral notion of democracy. ${ }^{17}$ We also include a lagged dependent variable with the expectation that where an observation was in terms of the development of civil society will strongly condition where it is at time $t^{18}$ We use a time-series cross-sectional design using random effects because of our desire to understand regional differences on the strength of civil society. ${ }^{19}$ Our sample is confined to the post-1989 period, the focus of the debate on the strength of postcommunist civil society. The results are presented below in table 2 .

\footnotetext{
14 The GDP per capita data come from the Maddison project, which have been uploaded into the V-Dem Data. See Bolt and Zanden (2014).

15 The eight regional dummies are modified versions of V-Dem's regional indicators (Coppedge et al. 2015d). For the postcommunist countries, we include the countries in the Balkans, East/Central Europe, the Caucasus, and Central Asia (except Afghanistan), plus Mongolia. Western Europe includes the Nordic countries, Southern and Western Europe. All Asian subregions and Afghanistan are categorized into Asia. Sub-Saharan Africa consists of Central Africa, East/Horn of Africa, Southern Africa, and West Africa. The Caribbean, Central and South America are combined into Latin America. The other three regions - Oceania, Middle East/North Africa, and North America - follow V-Dem.

${ }^{16}$ For an in-depth discussion of the variable see Coppedge, et al. (2015a, 37-38).

17 "The democratic method is that institutional arrangement for arriving at political decisions which realizes the common good by making the people itself decide issues through the election of individuals who are to assemble in order to carry out its will." (Schumpeter 2003:250).

18 This was confirmed by a Woolridge test for serial correlation.

19 We ran Breusch and Pagan Lagrangian multiplier tests to confirm that random effects were more appropriate than pooled OLS. Estimation was random-effects generalized least squares (GLS) using the xtreg command in Stata 13.
} 
Table 2: Correlates of Civil Society Robustness (CCSI) Using Random Effects TSCS Regressions (with V-Dem Clean Elections Index)

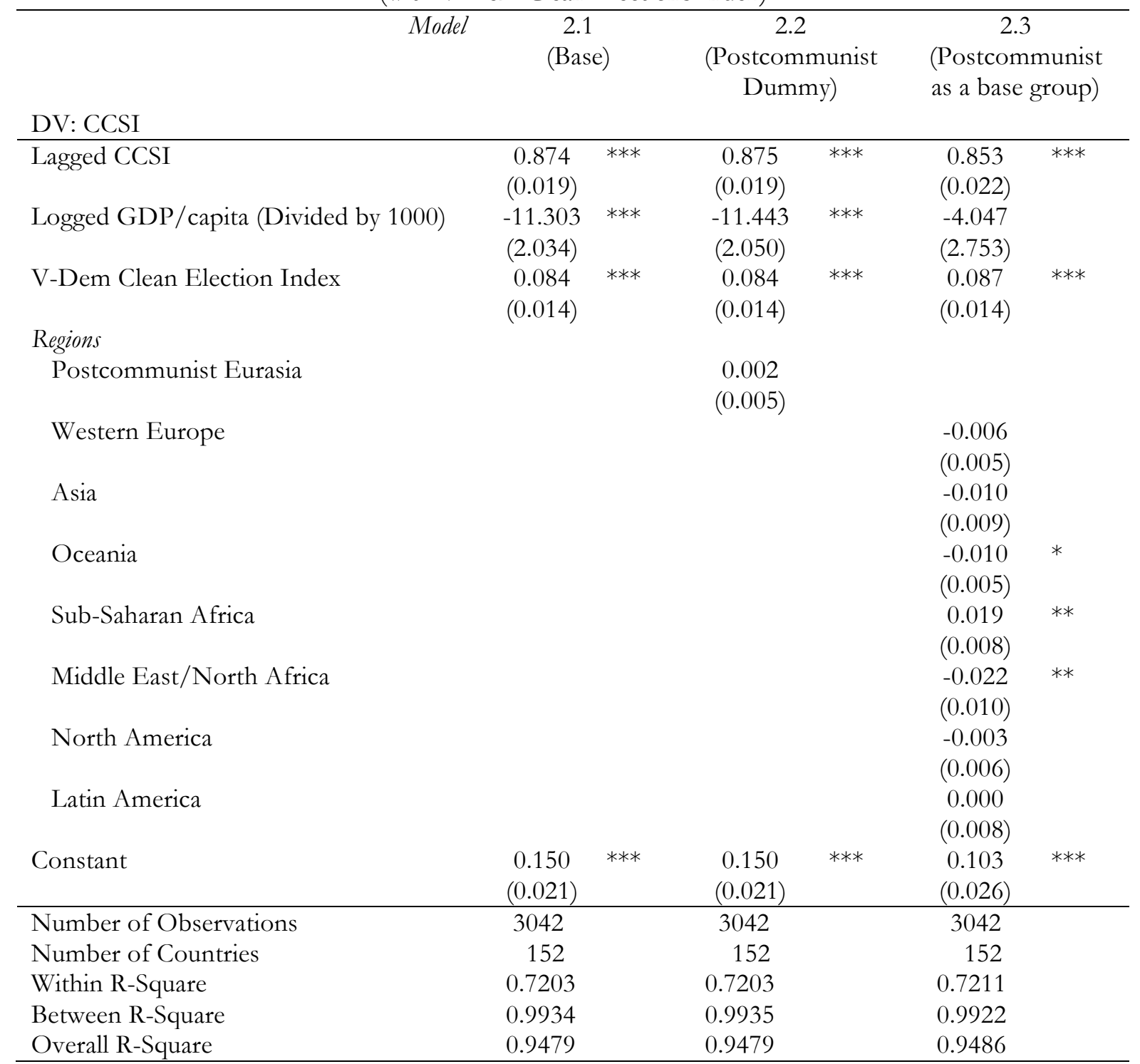

Two-tailed tests with robust standard errors in parentheses; ${ }^{* * *} \mathrm{p}<.01,{ }^{* *} \mathrm{p}<.05, * \mathrm{p}<.1$

In the base model (2.1) both democracy and development are significant. As expected both the level of democracy and lagged dependent variable (CCSI at t-1) are significant and positively related to CCSI. The log of the level of development is negative and significant, indicating that higher levels of economic development do not lead to a stronger civil society. Additional tests, less central to our analysis here, showed that the relationship is actually ushaped (see below, table 4 and figure 11).

When we add a dummy variable for postcommunist countries in model 2.2 it is insignificant, meaning that postcommunist countries are no more likely to have stronger or weaker civil societies than countries in other regions. And in the final model of the table (2.3) 
where postcommunist states are the omitted variable we find that given the controls civil society in postcommunist states are not statistically different than Western Europe, Asia, Latin America, or North America. The only significant findings are for Oceania and the Middle East and North Africa, which perform worse than the postcommunist states, and Sub-Saharan Africa, which outperforms the postcommunist states.

Table 3: Correlates of Civil Society Robustness (CCSI) using Random Effects TSCS Regressions (with Decades of Democracy by Boix-Miller-Rosato Coding of Democracy)

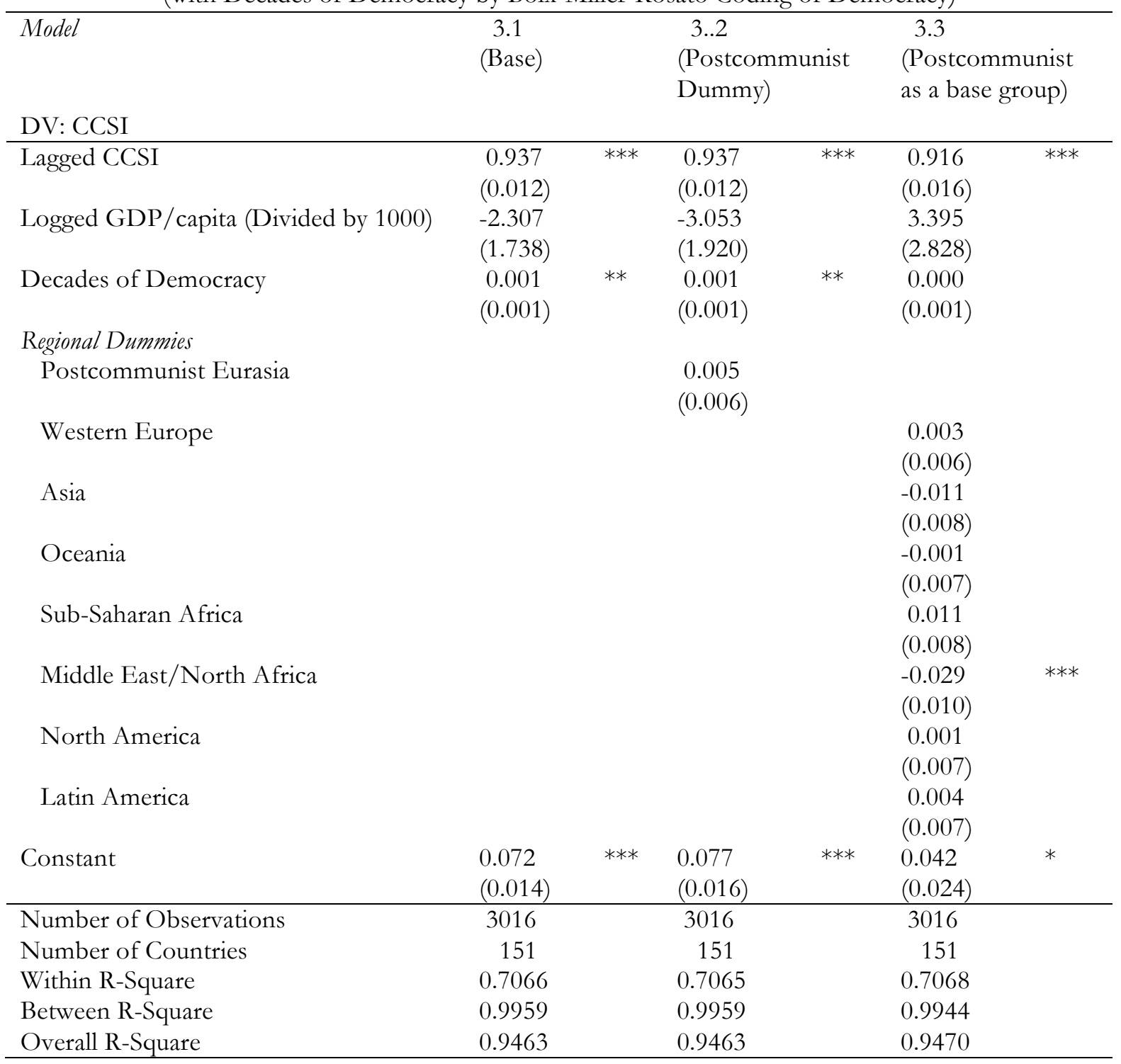

Two-tailed tests with robust standard errors in parentheses; ${ }^{* * *} \mathrm{p}<.01,{ }^{* *} \mathrm{p}<.05,{ }^{*} \mathrm{p}<.1$

In Table 3 we run similar models to capture whether democracy has a developmental effect over time (assuming more time under democracy will allow civil society to flourish). Because there is no theoretically justified cut-point to sort democratic from non-democratic 
practice using the Clean Elections Index, we use the binary coding by Boix, Miller and Rossato (2015) to estimate time spent under democracy. It too uses a minimalist, electoral specification of democracy.

The results for models 3.1 and 3.2 in this table strongly parallel those in Table 2 above. The control variables behave in the same way and the dummy for postcommunist states is not significantly different from the rest of the sample. In Model 3.3, where the postcommunist dummy marks the excluded group, very little is significant except for the lagged dependent variable, and the dummy for MENA shows that its level of civil society development is lower compared to the postcommunist states. Curiously the coefficient on GDP changes from negative to positive.

Table 4 reproduces Table 2 above while controlling for a quadratic (u-shaped) relationship between the GDP/capita and the CCSI. The quadratic specification is significant for the first two models but not the third. In these models there is little evidence that postcommunist civil society is very different from most regions in the world. It is marginally weaker in MENA, and is marginally stronger in Sub-Saharan Africa when the controls are taken into account.

Table 4: Correlates of Civil Society Robustness (CCSI) Using Random Effects TSCS Regressions (with V-Dem Clean Elections Index and Quadratic GDP/capita)

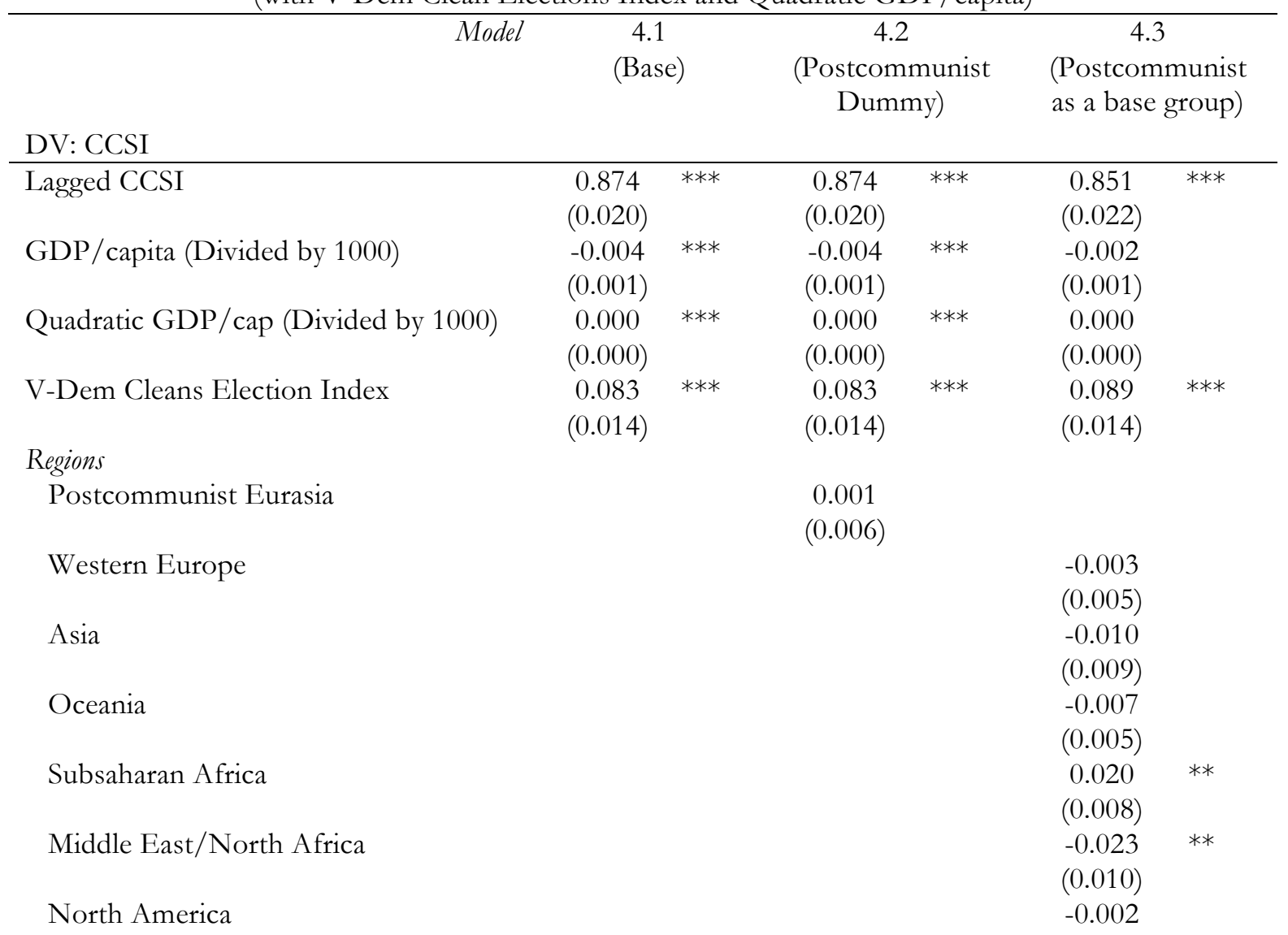




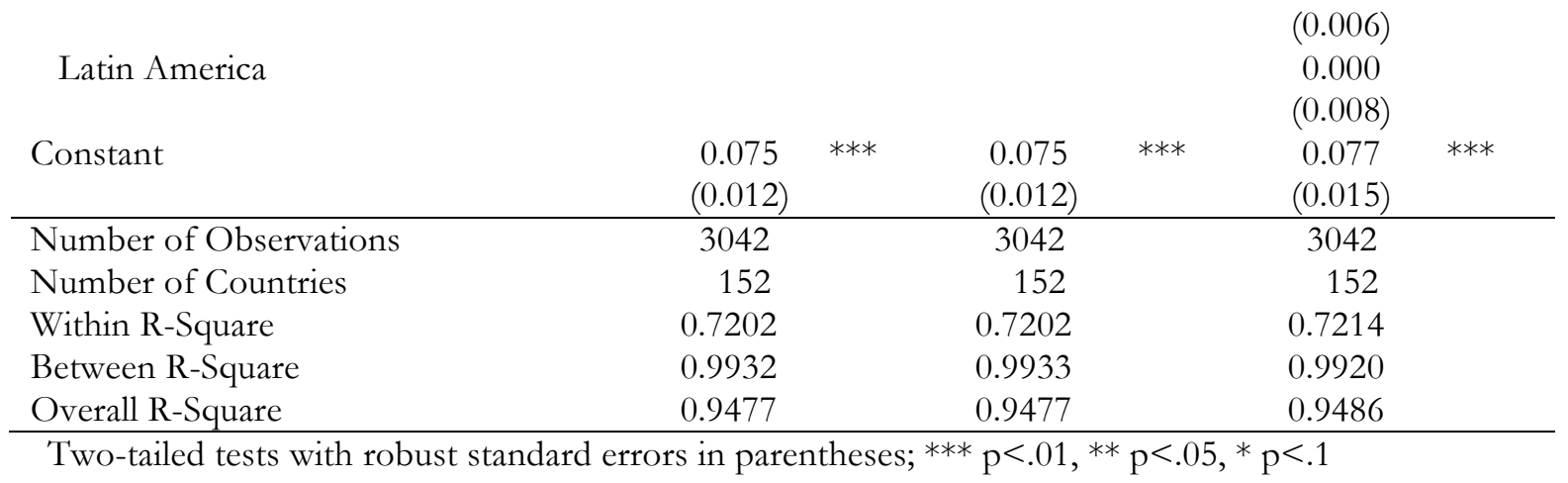

Figure 11 below is a fitted plot of the effect of GDP/capita in the quadratic specification on CCSI holding the other variables at their means using model 4.1. The inverted U shape shows that rising GDP/Capita has an initial negative effect on CCSI which turns positive at $\sim \$ 15,000$. The negative relationship in the linear model seems to be a product of the preponderance of observations below that level in the dataset.

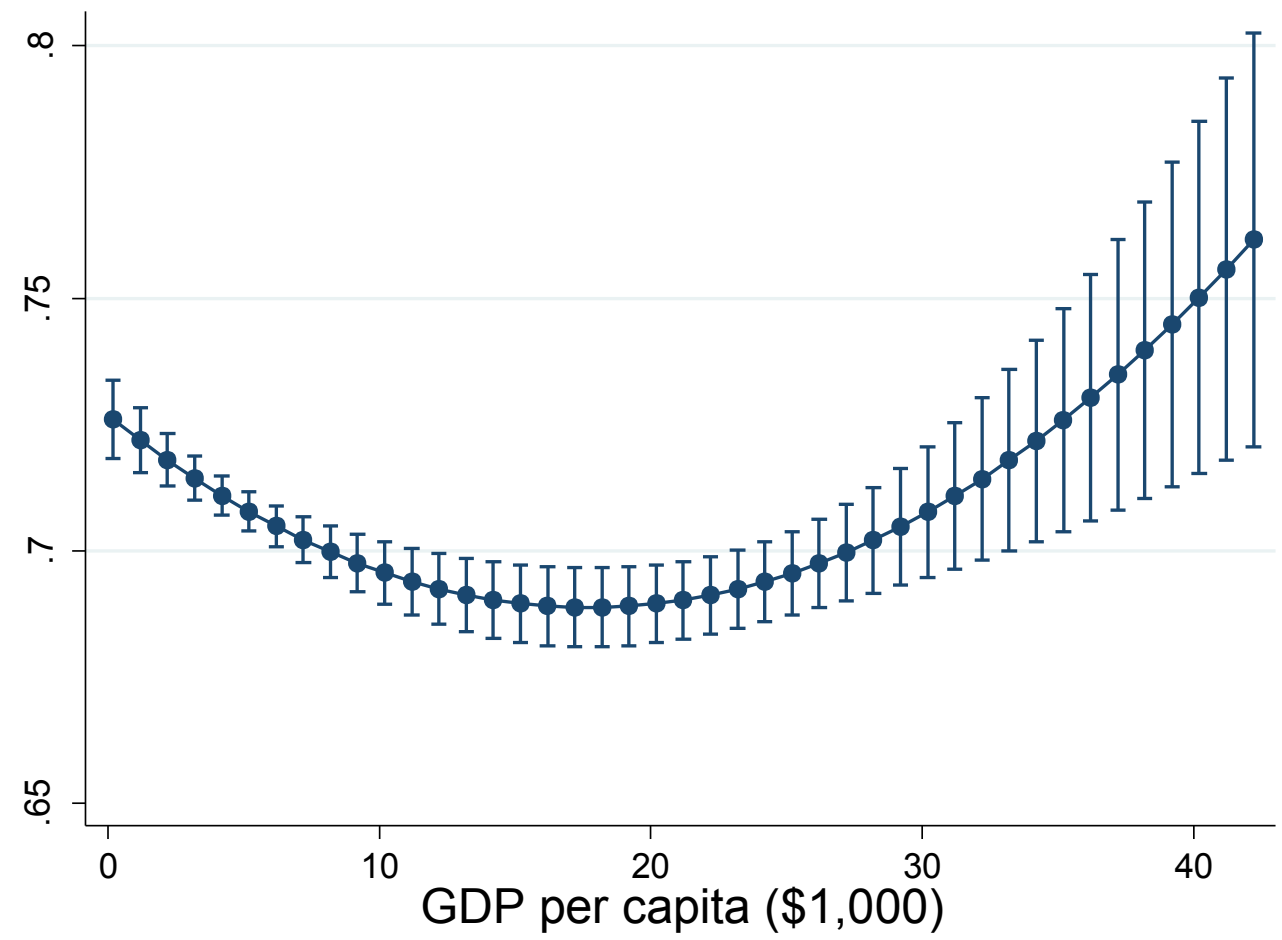

Figure 11: The Quadratic Relationship between GDP per Capita and the CCSI (with 95 percent confidence levels) 


\section{Robustness Checks}

To demonstrate that our findings on postcommunist civil society are robust we reran our models using other measures of democracy that do not use attributes that are part of the conceptualization of the CCSI in their mesurement strategy. In table 5 we duplicate the tests in table 2 using the graded scale version of Polity 2 (Marshall et al. 2011). The results were substantively unchanged.

Table 5: Correlates of Civil Society Robustness (CCSI) Using Random Effects TSCS Regressions (with Polity2)

\begin{tabular}{|c|c|c|c|c|c|c|}
\hline \multirow{2}{*}{$\begin{array}{l}\text { Model } \\
\text { DV: CCSI }\end{array}$} & \multicolumn{2}{|l|}{$\begin{array}{c}5.1 \\
\text { (Base) }\end{array}$} & \multicolumn{2}{|c|}{$\begin{array}{l}5.2 \\
\text { (Postcommunist } \\
\text { Dummy) }\end{array}$} & \multicolumn{2}{|c|}{$\begin{array}{l}5.3 \\
\text { (Postcommunist } \\
\text { as a base group) }\end{array}$} \\
\hline & & & & & & \\
\hline Lagged CCSI & $\begin{array}{l}0.900 \\
(0.019)\end{array}$ & *** & $\begin{array}{l}0.899 \\
(0.019)\end{array}$ & *** & $\begin{array}{l}0.869 \\
(0.021)\end{array}$ & $* * *$ \\
\hline Logged GDP/capita (Divided by 1000) & $\begin{array}{l}-2.602 \\
(1.620)\end{array}$ & & $\begin{array}{l}-2.456 \\
(1.603)\end{array}$ & & $\begin{array}{l}4.082 \\
(2.912)\end{array}$ & \\
\hline Polity2 Score & $\begin{array}{l}0.002 \\
(0.001)\end{array}$ & $* * *$ & $\begin{array}{l}0.002 \\
(0.001)\end{array}$ & *** & $\begin{array}{l}0.002 \\
(0.001)\end{array}$ & $* * *$ \\
\hline \multicolumn{7}{|l|}{ Regions } \\
\hline Postcommunist Eurasia & & & $\begin{array}{l}-0.003 \\
(0.005)\end{array}$ & & & \\
\hline Western Europe & & & & & $\begin{array}{l}0.007 \\
(0.005)\end{array}$ & \\
\hline Asia & & & & & $\begin{array}{l}-0.009 \\
(0.009)\end{array}$ & \\
\hline Oceania & & & & & $\begin{array}{l}0.003 \\
(0.005)\end{array}$ & \\
\hline Subsaharan Africa & & & & & $\begin{array}{l}0.023 \\
(0.009)\end{array}$ & $* * *$ \\
\hline Middle East/North Africa & & & & & $\begin{array}{l}-0.027 \\
(0.011)\end{array}$ & $* *$ \\
\hline North America & & & & & $\begin{array}{l}0.005 \\
(0.006)\end{array}$ & \\
\hline Latin America & & & & & $\begin{array}{l}0.008 \\
(0.007)\end{array}$ & \\
\hline Constant & $\begin{array}{l}0.095 \\
(0.018)\end{array}$ & $* * *$ & $\begin{array}{l}0.095 \\
(0.018)\end{array}$ & *** & $\begin{array}{l}0.057 \\
(0.026)\end{array}$ & $* *$ \\
\hline Number of Observations & 2901 & & 2901 & & 2901 & \\
\hline Number of Countries & 148 & & 148 & & 148 & \\
\hline Within R-Square & 0.6913 & & 0.6913 & & 0.6912 & \\
\hline Between R-Square & 0.9957 & & 0.9957 & & 0.9936 & \\
\hline Overall R-Square & 0.9524 & & 0.9524 & & 0.9531 & \\
\hline
\end{tabular}

In table 6 we duplicate the analysis in table 3 using Polity 2. To calculate the time under democracy, we considered a combined score of six or higher as democratic. Again the results were substantively unchanged. 
Table 6: Correlates of Civil Society Robustness (CCSI) Using Random Effects TSCS Regressions (with Decades of Democracy by Polity2)

\begin{tabular}{|c|c|c|c|c|c|c|}
\hline \multirow{2}{*}{$\begin{array}{l}\text { Model } \\
\text { DV: CCSI }\end{array}$} & \multicolumn{2}{|l|}{$\begin{array}{l}6.1 \\
\text { (Base) }\end{array}$} & \multicolumn{2}{|c|}{$\begin{array}{l}6.2 \\
\text { (Postcommunist } \\
\text { Dummy) }\end{array}$} & \multicolumn{2}{|c|}{$\begin{array}{l}6.3 \\
\text { (Postcommunist } \\
\text { as a base group) }\end{array}$} \\
\hline & & & & & & \\
\hline Lagged CCSI & $\begin{array}{l}0.928 \\
(0.013)\end{array}$ & *** & $\begin{array}{l}0.927 \\
(0.014)\end{array}$ & **** & $\begin{array}{l}0.903 \\
(0.017)\end{array}$ & **** \\
\hline Logged GDP/capita (Divided by 1000) & $\begin{array}{l}-1.735 \\
(1.901)\end{array}$ & & $\begin{array}{l}-1.889 \\
(2.073)\end{array}$ & & $\begin{array}{l}5.227 \\
(3.147)\end{array}$ & * \\
\hline Decades of Democracy & $\begin{array}{l}0.001 \\
(0.001)\end{array}$ & ** & $\begin{array}{l}0.001 \\
(0.001)\end{array}$ & $*$ & $\begin{array}{l}0.000 \\
(0.001)\end{array}$ & \\
\hline \multicolumn{7}{|l|}{ Regions } \\
\hline Postcommunist Eurasia & & & $\begin{array}{l}0.001 \\
(0.006)\end{array}$ & & & \\
\hline Western Europe & & & & & $\begin{array}{l}0.009 \\
(0.007)\end{array}$ & \\
\hline Asia & & & & & $\begin{array}{l}-0.009 \\
(0.010)\end{array}$ & \\
\hline Oceania & & & & & $\begin{array}{l}0.006 \\
(0.009)\end{array}$ & \\
\hline Subsaharan Africa & & & & & $\begin{array}{l}0.017 \\
(0.009)\end{array}$ & * \\
\hline Middle East/North Africa & & & & & $\begin{array}{l}-0.031 \\
(0.012)\end{array}$ & $* * *$ \\
\hline North America & & & & & $\begin{array}{l}0.007 \\
(0.008)\end{array}$ & \\
\hline Latin America & & & & & $\begin{array}{l}0.010 \\
(0.008)\end{array}$ & \\
\hline Constant & $\begin{array}{l}0.072 \\
(0.016)\end{array}$ & *** & $\begin{array}{l}0.073 \\
(0.017)\end{array}$ & *** & $\begin{array}{l}0.031 \\
(0.027) \\
\end{array}$ & \\
\hline Number of Observations & 2901 & & 2901 & & 2901 & \\
\hline Number of Countries & 148 & & 148 & & 148 & \\
\hline Within R-Square & 0.6895 & & 0.6895 & & 0.6894 & \\
\hline Between R-Square & 0.9955 & & 0.9955 & & 0.9932 & \\
\hline Overall R-Square & 0.9520 & & 0.9520 & & 0.9526 & \\
\hline
\end{tabular}

Two-tailed tests with robust standard errors in parentheses; ${ }^{* * *} \mathrm{p}<.01,{ }^{* *} \mathrm{p}<.05,{ }^{*} \mathrm{p}<.1$

In Table 7 we reproduce the analysis in table 2 using the binary measure of democracy developed by Boix, Miller, and Rosato (2015). Once again our findings are robust. 
Table 7: Correlates of Civil Society Robustness (CCSI) Using Random Effects TSCS Regressions (with Boix-Miller-Rosato Binary Coding of Democracy)

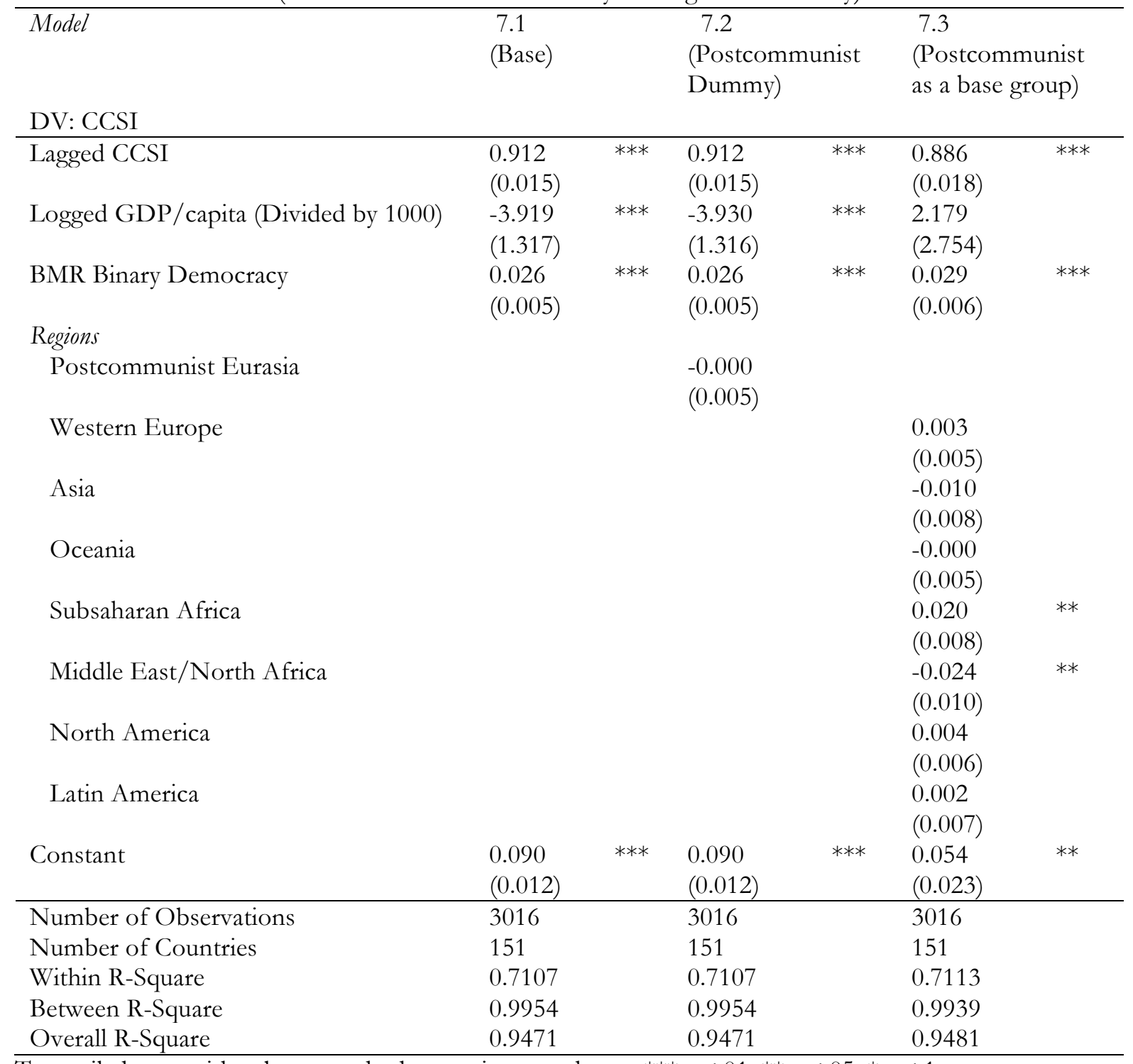

Two-tailed tests with robust standard errors in parentheses; ${ }^{* * *} \mathrm{p}<.01,{ }^{* *} \mathrm{p}<.05,{ }^{*} \mathrm{p}<.1$

Overall, the large number of tests we have performed here would seem to indicate that the development of civil society in the postcommunist world is not particularly different from that of other regions. Our findings are more congruent with the literature that argues that civil society in the postcommunist countries is not especially weak. We come at the problem from a rather different perspective though. Rather than using micro-level data, like the previous literature, we use a macro-level indicator, the V-Dem CCSI, and explicitly compare the region to all others globally over a large number of states, for a large block of time (rather than a sample truncated by survey availability bias or cross-sectional data). While this simple test may not definitively settle the debate, it is offered to show the new possibilities opened by the collection 
of the V-Dem dataset and the vast number of disaggregated indicators it contains, to address important substantive questions with a new perspective.

\section{Conclusions}

Since the emergence of civil society as an important substantive factor in our understanding of processes of democratization and the political life of democracy, our theoretical insights have suffered from a shortfall of comprehensive data that would allow us to subject them to rigorous testing using statistical methods and time-series data to validate generalizable knowledge about the effects of the strength of civil society. The new V-Dem core civil society index was designed with this purpose in mind. The version of the dataset that we used in our analysis contains over sixteen thousand country-year observations for the period 1900-2012 covering a range of sovereign-states, colonial dependencies, and other political entities. We hope that the validity tests and the basic test to adjudicate the dispute over the status of postcommunist civil society convinces the reader that this data can help to move important substantive debates on the impact of civil society on a range of outcomes. It also holds out the possibility to study what leads to different kinds of civil society. Other work by the V-Dem team has already gone a long way to demonstrate that robust civil society is a strong predictor of the survival of democracies both in a global sample and during the interwar period (Bernhard et al. 2015, Cornell et al. 2015). 


\section{References}

Almond, Gabriel, and Sidney Verba. 1963. The Civic Culture: Political Attitudes and Democracy in Five Nations. Princeton, Princeton University Press.

Anheier, Helmut and Sally Stares. 2002. "Introducing the Global Civil Society Index," in Global Civil Yearbook 2002, Marlies Glasius, Mary Kaldor and Helmut Anheier, eds. Oxford, Oxford University Press. 241-255.

Arato, Andrew. [1981] 1993. "Civil Society and the State, Poland 1980-81," From Neo-Marxism to Democratic Theory. Armonk, M.E. Sharpe. 71-211.

Berman, Sheri. 1997. "Civil Society and the Collapse of the Weimar Republic." World Politics, 49(3), 401-429.

Bermeo, Nancy and Philip Nord. 2000. Civil Society before Democracy: Lessons from Nineteenth-century Europe. Lanham, Rowman and Littlefield.

Bernhard, Michael. 1993. The Origins of Democratization in Poland: Workers, Intellectuals, and Oppositional Politics. New York, Columbia University Press.

Bernhard, Michael. 1996. "Civil Society after the First Transition: Dilemmas of Postcommunist Democratization in Poland and Beyond," Communist and Post-Communist Studies 29(3), 309-330.

Bernhard, Michael and Ekrem Karakoç. 2007. "Civil Society and the Legacies of Dictatorship." World Politics 59(4), 539-567.

Bernhard, Michael, Allen Hicken, Christopher Reenock and Staffan I. Lindberg. 2015. "Institutional Subsystems and the Survival of Democracy: Do Political and Civil Society Matter?" Varieties of Democracy Institute Working Paper No. 4. https://www.vdem.net/media/filer_public/62/8e/628e4e08-ffb4-45ee-84c5-a25032d1b0dc/vdem_working_paper_2015_4.pdf (accessed May 1, 2015).

Bertelsmann Stiftung. 2014a. BTI 2003-2014 Scores. http://www.btiproject.org/uploads/tx_itao_download/BTI2003-2014_Scores_02.xls (accessed August 10, 2015).

Bertelsmann Stiftung. 2014b. Transformation Index BTI 2014. Guetersloh, Verlag Bertelsmann Stiftung.

Barry, Brian. 1970. Sociologists, Economists, and Democracy. Chicago, University of Chicago Press.

Bobbio, Norberto. 1988. "Gramsci and the Concept of Civil Society," in Civil Society and the State, John Keane, ed. London, Verso. 73-99. 
Boix,Carles, Michael K. Miller, and Sebastian Rosato. 2015. "Dichotomous coding of democracy, 1800-2010," Version 2.0. $\quad \underline{\text { https://b2998732-a-62cb3a1a-s- }}$ sites.googlegroups.com/site/mkmtwo/Codebook-BMRv2.0.pdf (accessed August 1, 2015).

Bollen, Kenneth A. and Pamela Paxton. 2000. "Subjective Measures of Liberal Democracy." Comparative Political Studies 37(1), 58-86.

Bolt, Jutta and Jan Luiten van Zanden. 2014. "The Maddison Project: Collaborative Research on Historical National Accounts." The Economic History Review 67(3), 627-651.

Center for Civil Society Studies. 2004. Global Civil Society Index" http://ccss.jhu.edu/wpcontent/uploads/downloads/2011/12/Civil-Society-Index_FINAL_11.15.2011.pdf

(Accessed August 2, 2013).

Cingranelli, David L., David L. Richards, and K. Chad Clay. 2014. "The CIRI Human Rights Dataset." http://www.humanrightsdata.com. Version 2014.04.14 (Accessed August 1, 2015).

Civicus. 2011. "Civil Society Index: Key Findings from 2008-2011. http://www.civicus.org/news-and-resources-127/602-civicus-civil-society-index-key-findingsfrom-2008-2011 (Accessed August 2, 2013).

Civicus. 2012. "The Origins of the Classic CSI." http://www.civicus.org/what-we-do126/csi/classic-csi (Accessed August 2, 2013).

Civicus. 2013. The Civicus 2013 Enabling Environment Index. http://www.civicus.org/downloads/2013EEI\%20REPORT.pdf (Accessed June 14, 2015).

Clinton, Joshua, Simon Jackman, and Douglas Rivers. 2004. "The Statistical Analysis of Roll Call Data." American Political Science Review 98(2), 355-370.

Cohen, Jean and Andrew Arato. 1994. Civil Society and Political Theory. Cambridge, MIT Press.

Coppedge , Michael and John Gerring, with David Altman, Michael Bernhard, Steven Fish, Allen Hicken, Matthew Kroenig, Staffan I. Lindberg, Kelly McMann, Pamela Paxton, Holli A. Semetko, Svend-Erik Skaaning, Jeffrey Staton, and Jan Teorell. 2011. "Conceptualizing and Measuring Democracy: A New Approach.” Perspectives on Politics 9(2), 247-267.

Coppedge, Michael, John Gerring, Staffan I. Lindberg, Jan Teorell, David Altman, Michael Bernhard, M. Steven Fish, Adam Glynn, Allen Hicken, Carl Henrik Knutsen, Kelly McMann, Daniel Pemstein, Svend-Erik Skaaning, Jeffrey Staton, Eitan Tzelgov, Yi-ting Wang, Brigitte Zimmerman. 2015a. "Varieties of Democracy Codebook v4”. Varieties of Democracy Project: Project Documentation Paper Series.

Coppedge, Michael, John Gerring, Staffan I. Lindberg, Jan Teorell, David Altman, Michael Bernhard, M. Steven Fish, Adam Glynn, Allen Hicken, Carl Henrik Knutsen, Kelly McMann, Daniel Pemstein, Svend-Erik Skaaning, Jeffrey Staton, Eitan Tzelgov, Yi-ting Wang, Brigitte 
Zimmerman. 2015b. "Varieties of Democracy Dataset v. 4.2," Varieties of Democracy (VDem) Project.

Coppedge, Michael, John Gerring, Staffan I. Lindberg, Jan Teorell, David Altman, Michael Bernhard, M. Steven Fish, Adam Glynn, Allen Hicken, Carl Henrik Knutsen, Kelly McMann, Daniel Pemstein, Svend-Erik Skaaning, Jeffrey Staton, Eitan Tzelgov, Yi-ting Wang, and Brigitte Zimmerman. 2015c. "Varieties of Democracy: Methodology v4." Varieties of Democracy (V-Dem) Project.

Coppedge, Michael, John Gerring, Staffan I. Lindberg, Jan Teorell, Vlad Ciobanu. 2015d. "Varieties of Democracy: Country Coding Units v4." Varieties of Democracy Project: Project Documentation Paper Series.

Cornell, Agnes, Jørgen Møller, and Svend-Erik Skanning. 2015. "Democracy on Retreat: Crisis, State-Society Relations, and the Recurrence of Autocracy in the Interwar Years." Paper presented at the Council for European Studies Annual Conference, Paris, July 8-10, 2015.

Edwards, Bob, and Robert W. Foley. 1999. "Civil Society and Social Capital beyond Putnam." American Behavioral Scientist 42(1), 124-139.

Ekiert, Grzegorz. 1996. The State against Society. Princeton, Princeton University Press.

Ekiert, Grzegorz and Jan Kubik. 1999. Rebellious Civil Society. Ann Arbor, University of Michigan Press.

Ekiert, Grzegorz, Jan Kubik, and Michal Wentzel. 2014. "Civil Society and the Three Inequalities in Contemporary Poland.” (Unpublished manuscript).

Ekiert, Grzegorz and Roberto Foa. 2012. "The Weakness of Post-Communist Civil Society Reassessed," CES Papers - Open Forum 11, http://www.scribd.com/doc/107064389/TheWeakness-of-Post-Communist-Civil-Society-Reassessed (accessed August 1, 2013).

Encarnación, Omar G. 2003. The Myth of Civil Society: Social Capital and Democratic Consolidation in Spain and Brazil. New York, Palgrave Macmilllian.

Ferguson, Adam (1767 [1995]). An Essay on the History of Civil Society. London, Transaction Publishers.

Fernandes, Tiago and Rui Branco. 2013. "Civil Society and the Quality of Democracy: Portugal, 1974 - 2010," Presented at the 20th International Conference of Europeanists, Amsterdam, June 2013.

Foa, Roberto and Jeffery C. Tanner. 2012. "Methodology of the Indices of Social Development," Working Paper No. 2012-4. Rotterdam, Erasmus University, International Institute of Social Studies. 
Freedom House. 2012. "Nations in Transit: Methodology," http:/ / www.freedomhouse.org/template.cfm?page=352\&ana_page $=330 \& y e a r=2006$

(Accessed August 2, 2013).

Gramsci, Antonio. 1971. Selections from the Prison Notebooks of Antonio Gramsci. Edited and translated by Hoare. Q. and G.N. Smith. New York and London, International Publishers, Lawrence and Wishart.

Hegel, Georg Wilhelm Friedrich. 1820 [2001]. The Philosophy of Right. Kitchener, ONT, Batoche Books.

Howard, Marc. 2003. The Weakness of Civil Society in Post-Communist Europe. Cambridge: Cambridge University Press.

Inglehardt, Ronald and Christian Welzel. 2005. Modernization, Cultural Change and Democracy. Cambridge, Cambridge University Press.

Institute of Social Studies. 2015a. Civic Participation. Erasmus University, Rotterdam. http://www.indsocdev.org/civic-activism.html (accessed June 15, 2015).

Institute of Social Studies. 2015b. Clubs and Associations. Erasmus University, Rotterdam. http://www.indsocdev.org/clubs-and-associations.html (accessed June 15, 2015).

Jackman, Simon. 2004. "What Do We Learn from Graduate Students Committees? A Multiple Rater, Latent Variable Model, with Incomplete and Continuous Indicators.” Political Analysis 12(4), 400-424.

Keane, John. 1998. Civil Society: Old Images, New Visions. Cambridge, Polity Press.

King, Gary and Jonathan Wand. 2007. "Comparing Incomparable Survey Responses: Evaluating and Selecting Anchoring Vignettes." Political Analysis 15(1), 46-66.

Kolakowski, Leszek. 1974. "The Myth of Human Self-Identity," in The Socialist Idea: A Reappraisal, Leszek Kołakowski and Stuart Hampshire, eds. New York, Basic Books. 18-35.

Linz, Juan and Alfred Stepan. 1996. Problems of Democratic Transition and Consolidation: Southern Europe, South America, and Post-Communist Europe. Baltimore, Johns Hopkins University Press.

Marshall, Monte, Ted Robert Gurr, and Keith Jaggers. 2009. POLITY IV, Dataset Users' Manual, Center for Systemic Peace, http://www.systemicpeace.org/inscr/p4manualv2009.pdf (accessed July 21, 2010).

Marx, Karl. 1843 [1978]. “On the Jewish Question,” in The Marx-Engels Reader, Robert Tucker, ed. New York, Norton \& Company. 26-46.

O'Donnell, Guillermo, and Philippe Schmitter 1986. "Tentative Conclusions about Uncertain Democracies," in Transitions from Authoritarian Rule, Vol. 4, Guillermo O'Donnell, Phillippe Schmitter, and Laurence Whitehead, eds. Baltimore, Johns Hopkins. 1-72. 
Pemstein, Dan, Stephen A. Meserve and James Melton. 2010. "Democratic Compromise: A Latent Variable Analysis of Ten Measures of Regime Type.” Political Analysis 18(4), 426-449.

Pemstein, Dan, Eitan Tzelgov, and Yi-ting Wang. 2015. "Evaluating and Improving Item Response Theory Models for Cross-National Expert Surveys". Varieties of Democracy Institute: Working Paper No. 1.

Pop-Eleches, Grigore and Joshua Tucker. 2013. "Associated with the Past? Communist Legacies and Civic Participation in Post-Communist Countries." East European Politics and Societies 27(1), 45-68.

Przeworski, Adam. 1991. Democracy and the Market. Cambridge, Cambridge University Press.

Putnam, Robert. 1993. Making Democracy Work. Civic Traditions in Modern Italy. Princeton, Princeton University Press.

Riley, Dylan J. (2010). The Civic Foundations of Fascism in Europe: Italy, Spain, and Romania 1870-1945. Baltimore, Johns Hopkins University Press.

Rothstein, Bo. (2005). Social Traps and the Problem of Trust. Cambridge, Cambridge University Press.

Salamon, Lester M., S. Wojciech Sokolowski, and Associates. 2004. Global Civil Society: Dimensions of the Nonprofit Sector, Volume Two. Bloomfield CT, KumarianPress.

Schnakenberg, Keith E. and Christopher Farris J. 2014. "Dynamic Patterns of Human Rights Practices." Political Science Research and Methods 2(1), 1-31.

Schumpeter, Joseph. 2003. Capitalism, Socialism and Democracy. London, Routledge.

Seligson, Mitchell, and Edward Mueller. 1994. "Civic Culture and Democracy: The Question of Causal Relationships.” American Political Science Review 88(3), 635-654.

Stepan, Alfred. 1985. "State Power and the Strength of Civil Society in the Southern Cone of Latin America," in Bringing the State Back In, Peter B. Evans, Dietrich Rueschemeyer, and Theda Skocpol, eds. Cambridge: Cambridge University Press. 317-346.

Stepan, Alfred. 1988. Rethinking Military Politics. Princeton, Princeton University Press.

Tocqueville, Alexis de. [1820] 2004. Democracy in America. New York, Library of America.

USAID. 2012a. "2011 CSO Sustainability Index for Sub-Saharan Africa," http://www.usaid.gov/africacivilsociety (Accessed August 3, 2013).

USAID. 2012b. "The 2011 CSO Sustainability Index for Central and Eastern Europe and Eurasia,” $\quad$ http://transition.usaid.gov/locations/europe_eurasia/dem_gov/ngoindex/ (Accessed August 3, 2013).

Verba, Sidney. 1965. "Germany: The Remaking of Political Culture," in Political Culture and Political Development, Lucian Pye and Sydney Verba, eds. Princeton, Princeton University Press. Weber, Max. 1978. Economy and Society. Berkeley, University of California Press. 
Welzel, Christian, Ronald F. Inglehart, and Franziska Deutsch. 2005. "Social Capital, Voluntary Associations and Collective Action: Which Aspects of Social Capital Have the Greatest 'Civic' Payoff?" Journal of Civil Society 1(2), 121-146.

World Values Survey. 2013. "Documentation of the Values Surveys," http://www.wvsevsdb.com/wvs/WVSDocumentation.jsp?Idioma=I (accessed August 3, 2013). 